OPEN ACCESS

Edited by:

Daniela De Biase,

Sapienza Università di Roma, Italy

Reviewed by:

Jack Christopher Leo,

University of Oslo, Norway

Jesus L. Romalde,

Universidade de Santiago

de Compostela, Spain

*Correspondence:

Jose A. Guijarro

jaga@uniovi.es

Specialty section:

This article was submitted to Microbial Physiology and Metabolism,

a section of the journal

Frontiers in Microbiology

Received: 20 December 2017

Accepted: 08 May 2018

Published: 25 May 2018

Citation:

Mendez J, Cascales D,

Garcia-Torrico Al and Guijarro JA (2018) Temperature-Dependent Gene Expression in Yersinia ruckeri: Tracking Specific Genes by Bioluminescence

During in Vivo Colonization.

Front. Microbiol. 9:1098.

doi: 10.3389/fmicb.2018.01098

\section{Temperature-Dependent Gene Expression in Yersinia ruckeri: Tracking Specific Genes by Bioluminescence During in Vivo Colonization}

\author{
Jessica Mendez, Desirée Cascales, Ana I. Garcia-Torrico and Jose A. Guijarro* \\ Área de Microbiología, Departamento de Biología Funcional, Facultad de Medicina, Instituto de Biotecnología de Asturias, \\ Universidad de Oviedo, Oviedo, Spain
}

Yersinia ruckeri is a bacterium causing fish infection processes at temperatures below the optimum for growth. A derivative Tn5 transposon was used to construct a library of $Y$. ruckeri mutants with transcriptional fusions between the interrupted genes and the promoterless I $\mathrm{X} X \mathrm{CDABE}$ and lacZY operons. In vitro analysis of $\beta$-galactosidase activity allowed the identification of 168 clones having higher expression at $18^{\circ} \mathrm{C}$ than at $28^{\circ} \mathrm{C}$. Among the interrupted genes a SAM-dependent methyltransferase, a diguanylated cyclase, three genes involved in legionaminic acid synthesis and three transcriptional regulators were defined. In order to determine, via bioluminescence emission, the in vivo expression of some of these genes, two of the selected mutants were studied. In one of them, the acrR gene coding a repressor involved in regulation of the AcrABTolC expulsion pump was interrupted. This mutant was found to be highly resistant to compounds such as chloramphenicol, tetracycline, and ciprofloxacin. Although acrR mutation was not related to virulence in Y. ruckeri, this mutant was useful to analyze acrR expression in fish tissues in vivo. The other gene studied was osmY which is activated under osmotic stress and is involved in virulence. In this case, complemented mutant was used for experiments with fish. In vivo analysis of bioluminescence emission by these two strains showed higher values for acrR in gut, liver and adipose tissue, whereas osmY showed higher luminescence in gut and, at the end of the infection process, in muscle tissue. Similar results were obtained in ex vivo assays using rainbow trout tissues. The results indicated that this kind of approach was useful for the identification of genes related to virulence in Y. ruckeri and also for the in vivo and in vitro studies of each of the selected genes.

Keywords: Yersinia ruckeri, temperature regulated genes, bioluminescence, acrR, osmY

\section{INTRODUCTION}

Yersinia ruckeri is the etiological agent of "Enteric red mouth disease" of salmonids which causes important economic losses in the aquaculture industry. The bacterium is distributed worldwide and four serotypes were defined (Romalde et al., 1993). The most virulent is serotype O1 which has two biotypes 1 and 2 (Davies and Frerichs, 1989). Most outbreaks are caused by biotype 1, 
but in recent years biotype 2 has been associated with outbreaks in different parts of the world (Arias et al., 2007; Calvez et al., 2014).

A key environmental stress factor in outbreaks of most bacterial fish diseases in fish farms is water temperature. In some cases, outbreaks occur when water temperature drops to a certain value, as in the case of "Cold water vibriosis" (Enger et al., 1991) and "Cold water disease" (Cipriano and Holt, 2005). In other diseases, such as "lactococcosis," outbreaks are related to an increase in water temperature (Vendrell et al., 2006). Interestingly, a remarkable number of bacterial diseases in aquaculture, particularly those of freshwater, occurred at temperatures below the optimum for growth of the infecting bacteria (Guijarro et al., 2015). Bacterial genes activated under these conditions were identified in fish pathogens. Indeed, in Flavobacterium psychrophilum, Hesami et al. (2011) defined a set of genes that were up-regulated at $8^{\circ} \mathrm{C}$ versus $20^{\circ} \mathrm{C}$ by using suppression subtractive hybridization. In the same way, in Lactococcus garvieae several genes linked to virulence were up-regulated at $18^{\circ} \mathrm{C}$ versus $37^{\circ} \mathrm{C}$ (Aguado-Urda et al., 2013). In Aeromonas hydrophila a MALDI-TOF analysis of the extracellular products showed that a serine-metalloprotease, S-layer, flagellins and proteins related to the type III secretion system were up-regulated at $25^{\circ} \mathrm{C}$ versus $37^{\circ} \mathrm{C}$ (Yu et al., 2007). The two-component system PhoP-PhoQ of Edwardsiella tarda responds to changes in environmental temperature by activating type III and type VI secretion systems, both associated with virulence of the bacterium (Srinivasa Rao et al., 2003, 2004; Zheng et al., 2005; Wang et al., 2009; Chakraborty et al., 2010). In spite of these studies, little is known about the temperature-regulated virulence factors in fish-associated bacterial pathogens and even less about the systems involved in their regulation.

$Y$. ruckeri has an optimal growth temperature of $28^{\circ} \mathrm{C}$ but outbreaks of disease occur at temperatures around $18^{\circ} \mathrm{C}$. Virulence of Y. ruckeri is multifactorial and different genes were described as being involved in pathogenesis (Fernández et al., 2007a; Tobback et al., 2007; Kumar et al., 2015). Expression of some of these genes was higher at $18^{\circ} \mathrm{C}$ than at $28^{\circ} \mathrm{C}$ (Fernández et al., 2004). Thus, the expression of the traH-N operon encoding a putative type IV secretion system (Méndez et al., 2009), YhlA hemolysin (Fernández et al., 2007b), Yrplprotease (Méndez and Guijarro, 2013) and ruckerbactin, a catecholate siderophore iron acquisition system were up-regulated at $18^{\circ} \mathrm{C}$ versus $28^{\circ} \mathrm{C}$ (Fernández et al., 2004). Therefore, the temperature-dependent modulation of virulence genes in Y.ruckeri tends to optimize the expression of these in conditions mimicking those encountered in the host.

As opposed to human pathogenic Yersinia species in which virulence factors are induced at temperatures near the optimal for bacterial growth, there is no study related to how Y. ruckeri regulates virulence gene expression at temperatures below the optimum for growth. The results of previous studies carried out in Y. ruckeri (Fernández et al., 2004; Méndez and Guijarro, 2013), showed the need for the present investigation, whose goal was the selection and identification of $Y$. ruckeri genes expressed preferentially at $18^{\circ} \mathrm{C}$ versus $28^{\circ} \mathrm{C}$ due to their potential role as virulence factors. Using transcriptional fusions between
Y. ruckeri promoters and lux-lac operons inserted in the Tn5 transposon, 168 clones having higher $\beta$-galactosidase activity at $18^{\circ} \mathrm{C}$ than at $28^{\circ} \mathrm{C}$ in an EMB medium were selected. Two of them, carrying Tn5 lux-lac insertions in the acrR and osm $Y$ genes, a repressor of the AcrAB-TolC system and a gene induced under osmotic shock, respectively, were further characterized both in vitro and in vivo. This study presents a useful, practical approach for the identification and further analysis of genes involved in virulence and for the determination of their expression both in vitro and in vivo.

\section{MATERIALS AND METHODS}

\section{Bacterial Strains, Plasmids, and Culture Conditions}

E. coli strains (Table 1) were routinely grown in $2 \mathrm{x}$ TY $(16 \mathrm{~g} / \mathrm{L}$ tryptone, $10 \mathrm{~g} / \mathrm{L}$ yeast extract, $5 \mathrm{~g} / \mathrm{L} \mathrm{NaCl}$ ) broth and $2 \%$ agar, and $Y$. ruckeri strains (Table 1) in nutrient broth (NB) or nutrient $1.5 \%$ agar (NA) from VWR International and Tryptic Soy Broth (TSB) and Tryptic Soy 1.5\% agar (TSA) from Merck. Liquid cultures were incubated at $37^{\circ} \mathrm{C}$ for $E$. coli and at $18^{\circ} \mathrm{C}$ and $28^{\circ} \mathrm{C}$ for $Y$. ruckeri in orbital shakers at $250 \mathrm{rpm}$. Growth was monitored by determining the $\mathrm{OD}_{600}$. In order to detect changes in the $\beta$-galactosidase activity, EMB from Merck was used. This is a differential microbiological medium useful to distinguish between organisms that ferment lactose ( $\beta$-galactosidase positive) and those that do not ( $\beta$-galactosidase negative). The lactose fermenters would produce dark colonies whereas the non-fermenters would form translucent or pink ones. When required, the following compounds were added to the media: $10 \mu \mathrm{g} / \mathrm{mL}$ erythromycin, $0.1 \mu \mathrm{g} / \mathrm{mL}$ cefotaxime, $50 \mu \mathrm{g} / \mathrm{mL}$ kanamycin, $50 \mu \mathrm{g} / \mathrm{mL}$ streptomycin, or $100 \mu \mathrm{g} / \mathrm{mL}$ ampicillin, all from Sigma-Aldrich Co.

\section{Construction of Mini-Tn5 lux-lac Km2 Transposon}

Construction of pUT mini-Tn5 lux-lac Km2 (Table 1) was initiated by utilizing the pUT mini-Tn $5 \mathrm{Km} 2$ vector (de Lorenzo et al., 1990). First, a $6 \mathrm{~Kb}$ SphI DNA fragment harboring the lacZY operon lacking the promoter and terminator was removed by enzymatic digestion from the pIVET8 plasmid (Mahan et al., 1995) (Table 1) and ligated to the pUT vector, previously digested with the same enzyme and dephosphorylated. The ligation mixture was introduced in E. coli S17-1 $\lambda$ pir by electroporation. Transformed cells were selected on $2 \mathrm{x}$ TY media supplemented with ampicillin. The correct orientation of the lac $Z Y$ operon was defined by DNA sequencing using the Lacsec primer (Supplementary Table S1). Once the pUT mini-Tn5 lac Km2 vector was obtained, a $5.8 \mathrm{~Kb}$ NotI DNA fragment containing the luxCDABE operon was removed from the pCS26PAC vector (Bjarnason et al., 2003) and ligated into the NotI restriction size located at the $5^{\prime}$ end of the lacZY operon in the pUT miniTn5 lac Km2 vector. The ligation mixture was introduced by

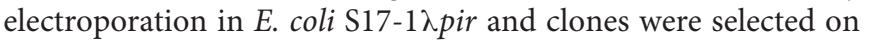
2x TY media containing ampicillin. Random clones were used 
TABLE 1 | Characteristics of the strains and plasmids used in this work.

\begin{tabular}{|c|c|c|}
\hline Strain or plasmid & Relevant properties & Source or reference \\
\hline \multicolumn{3}{|l|}{ Strains } \\
\hline \multicolumn{3}{|l|}{ E. coli } \\
\hline S17-1גpir & $\lambda$ (pir) hsdR pro thi RP4-2 Tc::mu Km::Tn7 & Simon et al., 1983 \\
\hline DH5 $\alpha \lambda$ pir & F'/endA1 hsdR17 (rk-mk+) supE44 thi-1 recA1 gyrA (Nal $\left.{ }^{R}\right) \lambda$ (pir) & Woodcock et al., 1989 \\
\hline \multicolumn{3}{|l|}{ Y. ruckeri } \\
\hline 150 & Strain of serotype 01 , biotype 1 isolated from an outbreak in trout. & J. L. Larsen, (Denmark) \\
\hline 150CTX & Strain 150 cultured in presence of cefotaxime & This work \\
\hline $150 \mathrm{acr}^{-}$ & acrR::mini-Tn5 luxlac Km2, $\mathrm{Km}^{r}$ & This work \\
\hline $150 \mathrm{acrR}^{+}$ & $\mathrm{acr}^{-}$con pGBM5::acrR & This work \\
\hline 150 osm $^{-}$ & osmY::mini-Tn5 luxlac Km2, $\mathrm{Km}^{\mathrm{r}}$ & This work \\
\hline 150 osm $^{+}$ & osm $Y^{-}$harboring pGBM5::osmY & This work \\
\hline 150 osm $^{++}$ & osm $Y^{-}$harboring pGBM5::osmY-ytjA & This work \\
\hline $150 \beta 1$ 1Т.B2 & Mini Tn5-luxlac mutant cultured in presence of cefotaxime & This work \\
\hline \multicolumn{3}{|l|}{ Plasmids } \\
\hline pCS26Pac & $\mathrm{Km}^{\mathrm{r}}, \mathrm{lu} \times C D A B E$ & Bjarnason et al., 2003 \\
\hline pGBM5 & $\mathrm{Spc}^{r} / \mathrm{Sm}^{r}$, promoter lac & Manen et al., 1997 \\
\hline pIVET8 & $A p^{r}$, oriR6K, mob+, cat-lacZY promotorless & Mahan et al., 1995 \\
\hline pUC19 & $A p^{r}$, cloning vector & Pharmacia \\
\hline pUT mini-Tn5 Km2 & $\mathrm{Ap}^{r}$, oriR6K, mobRP4, tnp, mini-Tn5 Km2 $\left(\mathrm{Km}^{r}\right)$ & de Lorenzo et al., 1990 \\
\hline pUT mini-Tn5 lac Km2 & pUT mini-Tn5 Km2 harboring trpAlacZY genes without promoter or transcription termination sequences & This work \\
\hline pUT mini-Tn5 luxlac Km2 & pUT mini-Tn5 Km2, harboring luxABCDE and trpAlacZY tandem genes without promoter & This work \\
\hline
\end{tabular}

for plasmid purification and further analysis by PCR and DNA sequencing in order to select those carrying the lux operon in the $5^{\prime}-3^{\prime}$ orientation with respect to $\operatorname{lac} Z Y$ and kanamycin-resistant genes. The obtained plasmid was named pUT mini-Tn5 lux-lac Km2 (Table 1).

In brief, pUT mini-Tn5 lux-lac Km2 plasmid was transferred

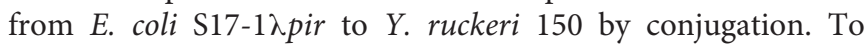
do that, $500 \mu \mathrm{l}$ of donor and $4 \mathrm{~mL}$ of recipient strains in exponential growth phase $\left(\mathrm{OD}_{600}, 0.6\right)$ were washed twice by centrifugation and resuspended in $10 \mathrm{~mL}$ of MilliQ water. Then, the suspension was filtered through a $0.45 \mu \mathrm{m}$ pore membrane that was transferred onto a $2 \mathrm{x}$ TY medium and incubated for $4 \mathrm{~h}$ at $28^{\circ} \mathrm{C}$. After incubation, the bacteria were resuspended in $2 \mathrm{~mL}$ of $\mathrm{NB}$ medium and aliquots of $50 \mu \mathrm{L}$ were spread onto NA medium containing kanamycin (resistance to which was conferred by the transposon) and erythromycin or cefotaxime, antibiotics to which Y. ruckeri 150 is intrinsically resistant. After incubation at $28^{\circ} \mathrm{C}$ for $48 \mathrm{~h}$, each selected transconjugant was transferred to a microtiter plate well containing $100 \mu \mathrm{L}$ of NB medium with kanamycin and erythromycin and incubated for $48 \mathrm{~h}$ at $28^{\circ} \mathrm{C}$. Triplicates of each plate were generated by using a Steer replicator, a multiple inoculator composed of 96 specifically spaced inoculating rods corresponding in position to the wells of a microtiter plate, and after incubation, glycerol was added to each well at a final proportion of $30 \%$. Plates were kept at $-80^{\circ} \mathrm{C}$ until use.

In order to determine the insertion pattern of the Tn5 lux-lac Km 2 transposon, 28 randomly selected insertion mutants were analyzed by Southern blot after digestion of the genomic DNA with SphI, using the $\mathrm{km}$ gene as a probe (Supplementary Table S1). Probe labeling, hybridization, and development were performed with the DIG DNA labeling and detection kit from Roche, following the manufacturer's instructions. After hybridization, high-stringency washes of the membrane was carried out to remove the $\mathrm{km}$ probe and plasmid insertion events were analyzed in the same membrane using as a probe the bla gene previously amplified by PCR from the pUT mini-Tn5 luxlac Km2 vector (Table 1). Transposon stability was assessed by repeated subculture of some mutants in non-selective TSB. After 3 days subculture, the numbers of cultivable cells on TSA with and without kanamycin were determined. The percentages of kanamycin-resistant bacteria were determined in relation to total cells.

\section{Selection and Identification of Promoters by Using $\beta$-Galactosidase Activity as a Marker}

In order to identify clones harboring transcriptional fusions between the lacZY operon and Y. ruckeri genes induced at $18^{\circ} \mathrm{C}$, the library of transconjugants was replicated twice onto plates containing EMB medium supplemented with kanamycin. One of these plates was incubated at $18^{\circ} \mathrm{C}$ and the other one at $28^{\circ} \mathrm{C}$ for 40 and $24 \mathrm{~h}$, respectively. After that, both replicas were analyzed to select those colonies having higher $\beta$-galactosidase activity, indicated by the colony having a more intense color, at $18^{\circ} \mathrm{C}$ than at $28^{\circ} \mathrm{C}$. Clones of interest were submitted to a second screening in the same conditions and then kept at $-80^{\circ} \mathrm{C}$ until use.

To identify the Tn5 lux-lac Km2 transposon insertion site in the selected clones, genomic DNA from each clone was digested with PstI, XbaI, or SphI and then ligated into the pUC19 plasmid previously digested with the corresponding 
enzyme and dephosphorylated. The resulting ligation mixture

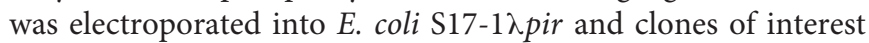
were further selected on $2 \mathrm{x}$ TY medium with ampicillin and kanamycin. These clones carried a DNA fragment harboring the kanamycin resistance gene from the transposon followed by a DNA fragment of variable length from the DNA located at the 3'position of the transposon insertion site. These fragments were sequenced using the TDKm6 primer (Supplementary Table S1) present at the end of the kanamycin resistance gene sequence and analyzed by RAST and BlastX programs.

\section{Complementation and Phenotypic Characterization of acrR and osm Y Mutants}

Complementation of acrR and osm $Y$ mutants was carried out by using plasmid pGBM5 (Table 1). acrR, osm $Y$, and os $m Y$ and the adjacent gene $y t j A$ (osmY ${ }^{++}$) were PCR amplified using the primers acrR-F/acrR-R, osmy-F/osmy-R and osmY-F/osmY-R2, respectively (Supplementary Table S1). All primers contained BamHI and PstI site at one end in order to clone the PCR-generated fragment into the BamHI-PstI restriction sites of the pGBM5 plasmid. The ligation mixture was introduced into E. coli $\mathrm{DH} 5 \alpha \lambda$ pir and transformants were selected on $2 \mathrm{x}$ TY medium with streptomycin. Restriction enzyme analysis, as well as PCR amplification of the generated plasmids, confirmed the correct structure and presence of the genes of interest. Constructions were transferred by electroporation to the respective mutants, and the appropriate clones were selected on TSA medium with kanamycin and streptomycin.

Susceptibility tests to antimicrobial agents and detergents were carried out in microtiter plates using twofold serial dilutions. Triplicate wells containing $5 \times 10^{4}$ cells of each strain and the respective compound to be tested were incubated at $18^{\circ} \mathrm{C}$ for $24 \mathrm{~h}$. The MIC was determined for each compound. The experiments were carried out in triplicate. The compounds assayed and the ranges of concentration were: acriflavine and chloramphenicol $0.02-40.96 \mu \mathrm{g} / \mathrm{mL}$; ciprofloxacin $0.02-1.28$ $\mu \mathrm{g} / \mathrm{mL}$; tetracycline $0.02-10.24 \mu \mathrm{g} / \mathrm{mL}$; SDS and Triton X-100, $0.0015-25.6 \%$.

To determine the effect of $\mathrm{n}$-hexane and bile salts on bacterial growth $10 \mu \mathrm{L}$ of a bacterial suspension of $10^{8} \mathrm{cfu} / \mathrm{mL}$ were deposited onto TSA medium in glass plates. After $10 \mathrm{~min}$, the culture medium was covered with a $3 \mathrm{~mm}$ layer of n-hexane and plates were incubated at $18^{\circ} \mathrm{C}$ for $72 \mathrm{~h}$. The effect of bile salts was assessed by spotting $10 \mu \mathrm{L}$ of 10 -fold serially diluted bacterial culture onto TSA media supplemented with $4 \%(\mathrm{w} / \mathrm{v})$ bile salts in a proportion of 85:15 sodium cholate and sodium deoxycholate that, according to Denton et al. (1974), corresponds with that found in the rainbow trout gut.

For motility assays, $2 \mu \mathrm{l}$ of overnight cultures of each strain were spotted onto TSA medium containing lactose $0.5 \%$ and $0.3 \%$ or $0.6 \%$ of agar; and in NA with $0.6 \%$ agar and different concentrations of glucose and lactose (glucose $0.25 \%$, glucose $0.5 \%$, lactose $0.75 \%$, and lactose $0.5 \%+$ glucose $0.25 \%$ ). Plates were incubated at 18 and $28^{\circ} \mathrm{C}$ for 3 days.

\section{Real-Time PCR Validation}

Total RNA was extracted from two biological replicates of $Y$. ruckeri 150 grown at the early stationary phase $\left(\mathrm{OD}_{600}\right.$ $\approx 1.1$ ) in $\mathrm{TSB}$ at $28^{\circ} \mathrm{C}$ and $18^{\circ} \mathrm{C}$. The cultures were fixed using $\mathrm{RNA}^{\mathrm{TM}}$ Protect Bacterial Reagent (Qiagen Inc.) in a ratio of $1 \mathrm{~mL}$ of reagent per $0.5 \mathrm{~mL}$ of bacterial culture. Centrifugation was used to pellet the cells and RNA was extracted in RNase-/DNase-free water using the High Pure RNA Isolation Kit (Roche). After three treatments with RNase-free DNase (Ambion) to eliminate DNA contamination, total RNA was quantified using micro-spectrophotometry (Nanodrop ND-1000, Nanodrop Technologies, EEUU). The RNA quality was estimated using an Agilent 2100 Bioanalyzer and RNA samples with an RNA Integrity Number (RIN) above 9.5 were selected.

cDNA synthesis was performed from $1 \mu \mathrm{g}$ of total RNA using the High Capacity cDNA Reverse Transcription Kit (Applied Biosystems, United States) and random primers according to the manufacturer's instructions. Samples in which reverse transcriptase had not been added were used as negative controls. The cDNAs were subsequently quantified by real-time PCR amplification on an ABI PRISM 7900 Sequence Detection System (Applied Biosystems) with primers specifics to the $y r p 1$ (Yrp1-qF: 5'-TGCGCAAACCAATAT CAGCG-3'; Yrp1-qR: 5' -TGCGCAAACCAATATCAGCG3'), acrR (AcrR-qF: 5'-CGTGCTTATATCACCGGCCT-3'; AcrR-qR: $\quad 5^{\prime}$-AGGCATTGCGCGATCATTTC-3'), osm $Y$ (Osmy-qF: 5' -CGGTTAGCGAATATGCCGGT-3'; OsmY-qR: 5' ACAAAACCACGCCATCGGTA-3') and 16S (16S-F: $5^{\prime}-\mathrm{TTTG}$ TTGCCAGCACGTAATGGT-3'; and 16S-R: $5^{\prime}$-GCGAGTT CGCTTCACTTTGTATCT-3') genes and using the SYBR Green PCR Master Mix (Applied Biosystems, United States).

Expression level results were standardized relative to the transcription level of the housekeeping gene 16S rRNA for each isolate. The relative change in the $y r p 1, a c r R$, and $\operatorname{osm} Y$ was calculated as the ratio of reference target using the $\Delta \Delta \mathrm{Ct}$, where $\mathrm{Ct}$ is the cycle threshold. Real-time PCR was carried out on two independent biological replicates each containing three technical replicates. The results are represented as the mean $\pm \mathrm{SD}$.

\section{Virulence Determination}

For rapid virulence screening of mutant strains in the genes coding for AcrR, OsmY, hypothetical protein OEU24935.1, polymyxin resistance ArnC, hypothetical protein OEU21186.1, esterase YqiA and UDP- $N$-acetylglucosamine 4,6-deshydratase, a total of 10 fish, average weight 6-8 g, were intraperitoneally injected with $0.1 \mathrm{~mL}$ of $10^{3} \mathrm{cfu} / \mathrm{mL}$ of each mutant.

For virulence determination of $a c r R^{-}$and osmY-strains, 15 rainbow trout fry distributed in three groups were intraperitoneally injected with $0.1 \mathrm{~mL}$ of $10^{7} \mathrm{cfu} / \mathrm{mL}$ of each strain. The fish were kept in $70 \mathrm{~L}$ tanks at $18^{\circ} \mathrm{C}$ and mortalities were recorded each day for a week and compared with those produced by the parental strain. The data were analyzed with Chi-square test. $P<0.05$ was considered statistically significant.

$\mathrm{LD}_{50}$ experiments by intraperitoneal injection with the parental, acrR mutant and $a c r R^{+}$complemented strains were carried out as described by Fernández et al. (2002). The doses 
injected ranged from 10 to $10^{8} \mathrm{cfu}$ per fish and mortalities were followed up to 7 days. The $\mathrm{LD}_{50}$ values were calculated by the method of Reed and Muench (1938). Bath infection was carried out by immersion of the fish for $1 \mathrm{~h}$ in $10 \mathrm{~L}$ dechlorinated water containing a final concentration of $10^{7} \mathrm{cfu} / \mathrm{mL}$ of the different strains. The fish were then transferred to $70 \mathrm{~L}$ tanks and mortalities were followed up to 7 days. In both challenges, dead fish were withdrawn every day and samples from internal organs were spread onto TSA medium. After $48 \mathrm{~h}$ of incubation at $28^{\circ} \mathrm{C}$ several colonies of the predominant bacteria were identified by PCR in order to confirm that they corresponded to the previously injected strain.

All the experiments carried out with fish were authorized and supervised by the Ethics Committee of Oviedo University.

\section{Real-Time Visualization of Y. ruckeri Promoter Expression}

Three groups of 30 fish weighing from 8 to $10 \mathrm{~g}$ were infected with Y. ruckeri $a c r R^{-}$and $o s m Y^{++}$strains. The $a c r R^{-}$strain was used in both intraperitoneal and immersion infection experiments. Thus, one group of 30 fish was infected by intraperitoneal injection using $10^{6} \mathrm{cfu}$ per fish and another group of 30 individuals was kept in a $10 \mathrm{~L}$ tank of dechlorinated water in contact with the $a c r R$ mutant at a concentration of $10^{7} \mathrm{cfu} / \mathrm{mL}$ for $1 \mathrm{~h}$. Infection challenge using $o s m Y^{++}$was only carried out by intraperitoneal injection following the procedure used for acrR. After infection, fish were transferred to tanks containing $70 \mathrm{~L}$ of dechlorinated water at $18^{\circ} \mathrm{C}$. At $24 \mathrm{~h}$ intervals over a 7 day period, fish were euthanized by overdose of ethylene glycol monophenyl ether, dissected and analyzed with IVIS Imaging System (Xenogen) to monitor the bacterial progression and expression of acrR and osm $Y$ genes in the fish organs. Each experiment was repeated twice to ensure data accuracy.

To analyze gene expression using different rainbow trout tissues, each strain was spread on plates containing TSA medium for confluent growth. Then, fish tissues were deposited onto the medium. Plates were incubated at $18^{\circ} \mathrm{C}$ overnight and luminescence analyzed by Ivis Lumina.

\section{RESULTS}

\section{Development of a Vector to Generate a Dual Reporter lux-lac Transcriptional Fusion Library in Y. ruckeri}

To create an appropriate dual reporter cassette for the analysis of differential gene expression in Y. ruckeri and also in other Gram-negative bacteria, we have modified the original pUT mini-Tn $5 \mathrm{Km} 2$ plasmid, a $\lambda$ pir-dependent delivery vector. Inside the mini-Tn $5 \mathrm{Km} 2$ transposon and at the $5^{\prime}$ end of the kanamycin gene, the promoterless luxCDABE operon from Photorhabdus luminescens (Meighen and Szittner, 1992) and lacZY genes from the pIVET8 plasmid (Mahan et al., 1995) were inserted (Figure 1A). The resulting plasmid, named pUT-mini Tn5 lux-lac

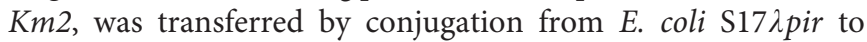
Y. ruckeri 150. Since the latter lacks the Pir protein necessary for

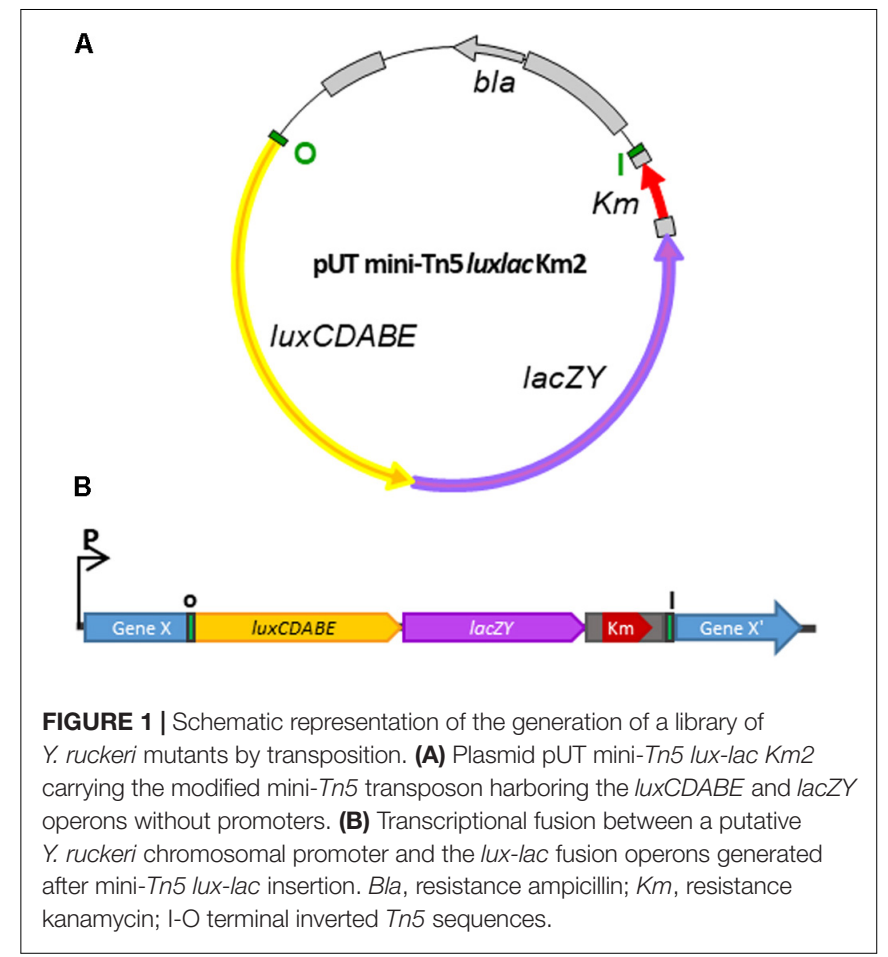

the replication of the pUT plasmid, transconjugants must have randomly integrated the transposon (Tn5 lux-lac Km2) into their genomes. Insertion of the mini Tn5 lux-lac Km2 transposon into the $Y$. ruckeri genome generated, in many cases, transcriptional fusions between the promoter of the interrupted gene by the transposon and the lux-lac cassette (Figure 1B). In that way, the capture of promoters transcribing the lux-lac fusions was useful to determine in vitro and in vivo promoter regulation of different genes under specific conditions.

A library of 14,724 individual $Y$. ruckeri transconjugants harboring Tn5 lux-lac Km2 insertions was generated. To determine if the transposon insertion in the genome of each cell was a random, plasmid-independent and unique event as it was previously described (Herrero et al., 1990), 28 kanamycin-resistant colonies were arbitrarily selected and subjected to Southern blot analysis. Each of the clones analyzed showed a single hybridizing fragment of a particular size when the kanamycin gene was used as a probe (Supplementary Figure S1A) indicating that the transposon insertion occurred randomly and only one time in the Y. ruckeri genome. When the ampicillin gene present in the plasmid was used as a probe not a single transconjugant showed a hybridizing signal (Supplementary Figure S1B). These results are consistent with those found by other authors.

\section{Characterization and Identification of Temperature-Regulated Promoters by Using lux-lac Reporters}

Y. ruckeri transconjugants were screened at $18^{\circ}$ and $28^{\circ} \mathrm{C}$ for differential $\beta$-galactosidase activity in EMB medium (Figure 2A). A total of 168 clones (1.14\%) displaying higher $\beta$-galactosidase 
A

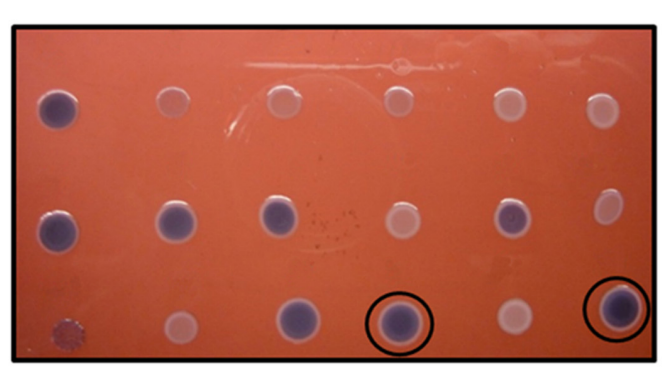

$28^{\circ} \mathrm{C}$

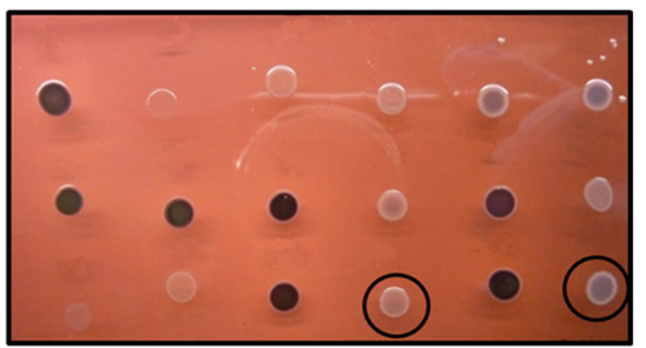

B

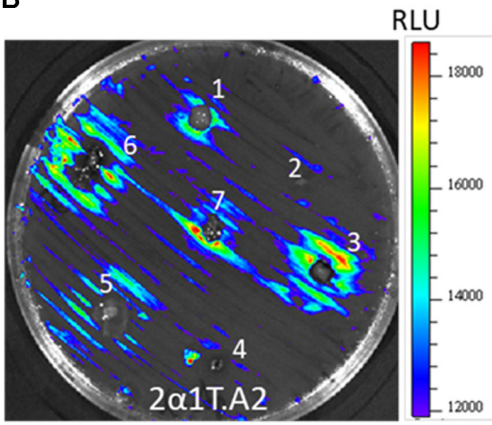

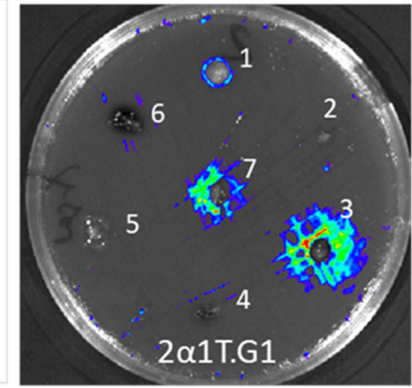

FIGURE 2 | Temperature differential gene expression of $Y$. ruckeri clones containing the Tn5-lux-lac transposon insertion. (A) $\beta$-galactosidase activity on EMB medium after incubation at $18^{\circ} \mathrm{C}$ and $28^{\circ} \mathrm{C}$. Circled colonies represent two examples of differential expression depending on the temperature. (B) Bioluminescence emission by different $Y$. ruckeri clones after $24 \mathrm{~h}$ of incubation at $18^{\circ} \mathrm{C}$ in the presence of different rainbow trout (O. mykiss) organs which were distributed on the surface of TSA plates: brain (1); heart (2); liver (3); spleen (4); adipose tissue (5); gut (6); gills (7), 2B. Bar indicating the correlation between luminescence (RLU) and color.

activity, indicated by a more intense purple-black color at $18^{\circ} \mathrm{C}$ than at $28^{\circ} \mathrm{C}$ in the experimental conditions, were selected. Analysis of these clones by an Ivis Lumina apparatus showed that there was correspondence between the light emission level and $\beta$-galactosidase activity in most cases (data not shown).

The transposon insertion sites were mapped for 33 out of 168 selected clones and the identified genes are shown in Table 2. The growth culture patterns of several temperature-regulated mutants were similar to each other and also to the parental strain, indicating that the energy cost resulting from the differential expression of the lux-lac operons, both present in a single copy in the chromosome, had no major effect on the bacterial physiology (data not shown). For two clones, the existence of a linear correlation between cell number, in the range of $10^{2}$ and $10^{7}$ cfu, and luminescence with $R^{2}$ values of 0.9593 and 0.9865 , respectively, was also determined.

In order to determine whether or not luminescence signals were useful in analyzing Y. ruckeri gene expression ex vivo, different randomly selected mutants were confluent spread on TSA medium. Tissue sections of several rainbow trout organs were deposited onto the culture and after $24 \mathrm{~h}$ of incubation at $18^{\circ} \mathrm{C}$ differences in the light emission displayed by the bacteria surrounding the different tissues were observed (Figure 2B). Thus, the gene interrupted in the 2a1T.A2 mutant showed highest light emission in liver, gills and gut tissues, whereas 2a1T.G1 and 2a1T.F5 mutants displayed the highest light emission in gills and liver, and gut and liver, respectively (Figure 2B).
Virulence determination was assessed in several of the selected mutants. Using intraperitoneal injection, 7 days post infection the parental strain produced $70 \%$ mortality, whereas mortalities for the selected mutants were: AcrR regulator, 80\%; hyperosmotic protein OsmY, 0\%; Hypothetical protein OEU24935.1, 30\%; polymyxin resistance ArnC, 50\%; Hypothetical protein OEU21186.1, 60\%; Esterase YqiA, 50\%; and UDP- $N$-acetylglucosamine 4,6-deshydratase, $0 \%$.

\section{Analysis of the Mutations in the Temperature-Regulated Genes acrR and osmY}

In order to check if the strategy developed to identify temperature-regulated genes allowed us to select the appropriate clones, two of the mutants harboring transcriptional fusions between the acrR and osm $Y$ promoters and the lux-lac operons were chosen for further analysis. The acrR mutant was selected because it was found to be as virulent as the parental strain, whereas the osm $Y$ mutant was attenuated. In this way, each of them was useful for the in vivo monitoring of the infection process: the $a c r R$ mutant as a positive control and the $\operatorname{osm} Y$ mutant to confirm its attenuation in virulence which should revert with the introduction of osm $Y$ gene in trans.

First, the differences in $\beta$-galactosidase activity displayed by the two mutants in $\mathrm{EMB}$ at $18^{\circ} \mathrm{C}$ in relation to $28^{\circ} \mathrm{C}$ 
TABLE 2 | Products of Y. ruckeri interrupted genes by the Tn5-lux-lac transposon.

\begin{tabular}{|c|c|c|c|c|c|}
\hline Gene product & Accession number & Gene product & Accession number & Gene product & $\begin{array}{l}\text { Accession } \\
\text { number }\end{array}$ \\
\hline Metalloprotease Yrp1 & CAC39217.1 & $\begin{array}{l}\text { Galactose/methyl galactoside } \\
\text { import ATP-binding protein }\end{array}$ & OEU26755.1 & Tn7-like transposition protein & OEU24391.1 \\
\hline Diguanylate cyclase & OEU26487.1 & Glycogen phosphorylase & OEU26568.1 & $\begin{array}{l}\text { ADP-ribosyltransferase } \\
\text { exoenzyme family protein }\end{array}$ & KGA50131.1 \\
\hline Glycosyltransferase & OEU24749.1 & 4-alpha-glucanotransferase & OEU26314.1 & PsiF repeat protein & EEQ00620.1 \\
\hline $\begin{array}{l}\text { SAM-dependent } \\
\text { methyltransferase }\end{array}$ & OEU24750.1 & $\begin{array}{l}\text { UDP-N-acetylglucosamine } \\
\text { 4,6-dehydratase }\end{array}$ & OEU25693.1 & Putative esterase (YqiA) & AJI94468.1 \\
\hline $\begin{array}{l}\text { Serine/threonine protein kinase } \\
\text { (anti-sigma regulatory factor) }\end{array}$ & OEU26573.1 & $\begin{array}{l}\text { D-Glycero-D-manno-heptose } \\
\text { 1-phosphate } \\
\text { guanosyltransferase }\end{array}$ & OEU25698.1 & Hypothetical protein & OEU24382.1 \\
\hline Response regulator (YsrR) & OEU25024.1 & O-antigen polymerase & ABY48117.1 & Hypothetical protein & OEU24387.1 \\
\hline $\begin{array}{l}\text { DNA-binding transcriptional } \\
\text { repressor AcrR }\end{array}$ & OEU24368.1 & O-acyltransferase & OEU26581.1 & Hypothetical protein & KGA49879.1 \\
\hline $\begin{array}{l}\text { Osmotically inducible protein } \\
\text { Osmy }\end{array}$ & OEU26500.1 & $\begin{array}{l}\text { Putative peptidoglycan } \\
\text { deacetylase }\end{array}$ & OEU25943.1 & Hypothetical protein & OEU24935.1 \\
\hline $\mathrm{Co} / \mathrm{Mg} / \mathrm{Ni}$ transporter & OEU26742.1 & $\begin{array}{l}\text { Antitoxin of toxin-antitoxin } \\
\text { stability system }\end{array}$ & OEU25145.1 & Hypothetical protein & EEP98349.1 \\
\hline MFS transporter & OEU26751.1 & Cell division protein (DamX) & EEP98349.1 & Hypothetical protein & OEU25186.1 \\
\hline Phosphoporin PhoE & OEU26976.1 & $\begin{array}{l}\text { Polymyxin resistance protein } \\
\text { ArnC }\end{array}$ & OEU24187.1 & Hypothetical protein & OEU24718.1 \\
\hline
\end{tabular}

were quantified by the Miller method using $o$-nitrophenyl- $\beta$-Dgalactopyranoside (ONPG) as a substrate. The results confirmed that both genes, acrR and osm $Y$, were highly expressed at $18^{\circ} \mathrm{C}$ (2860.6 \pm 158.3 and $786.6 \pm 42.1$ Miller units, respectively) in relation to $28^{\circ} \mathrm{C}(1439.8 \pm 11.9$ and $583.4 \pm 15.4$ Miller units). Moreover, in order to confirm the upregulation of acrR and $o s m Y$ genes at $18^{\circ} \mathrm{C}$ compared to $28^{\circ} \mathrm{C}$ (used as a reference), SYBR Green $\mathrm{qPCR}$ was carried out using $y r p 1$ as positive control of expression at $18^{\circ} \mathrm{C}$. According to the qRT-PCR analysis, yrp1, acrR and $o s m Y$ transcription increased about three times at $18^{\circ} \mathrm{C}$ compared to $28^{\circ} \mathrm{C}$ (Supplementary Figure S2).

Once the higher expression of acrR and osm $Y$ genes at low temperature had been corroborated, their implication in the physiology and virulence of $Y$. ruckeri was investigated.

\section{Phenotypic Characterization and Virulence Determination of the acrR Mutant and Complemented Strain acr $R^{+}$}

The acrR gene from Y. ruckeri encodes for a 216 amino acid protein belonging to the TetR transcriptional repressor family, with high identity (80\%) with the AcrR protein from Y. pestis (EFA48822.1) among other bacteria. This protein is a repressor which modulates the expression of the $\operatorname{acr} A B$ operon, which is located upstream and in the opposite direction of the $a c r R$ gene in the Y. ruckeri genome (Supplementary Figure S3). Binding of AcrR to the operator region located between the $\operatorname{acr} R$ and $\operatorname{acr} A B$ genes (Supplementary Figure S3) represses, in E. coli, both the expression of the $a c r A B$ operon, thus preventing its excessive expression, and also its own expression (Deng et al., 2013).

The AcrAB is part of the AcrAB-TolC pump involved in the expulsion of different toxic compounds from bacteria. Thus, as expected, the acrR mutant strain was more resistant than the parental strain to the antibiotics ciprofloxacin, chloramphenicol, tetracycline and also to acriflavine (Table 3 ). In the same way, the mutant strain turned out to be highly resistant to hexane, whereas the parental strain was sensitive (data not shown). The complemented mutant $a c r R^{+}$presented a similar phenotype to the parental strain, although it was a little more sensitive to the effect of all the antibiotics (Table 3). However, no differences were found between the parental and mutant strains in the sensitivity to detergents such as SDS and Triton X100. Interestingly, both strains were found to be resistant to bile salts when they were added at $4 \%$ to TSA medium, whereas the $a c r R^{+}$strain was highly sensitive (Figure 3).

The $a c r R^{-}$mutant developed bigger colonies that the parental and $a c r R^{+}$complemented strains when they were grown in TSA medium containing lactose $0.5 \%$ (Figure 4 ). The reason is that in this medium, when the percentage of agar was lowered to $0.3 \%$ or $0.6 \%$, the $a c r R$ mutant showed swimming and swarming motility, respectively. However, no motility at all was observed for the parental and complemented $a c r R^{+}$strains (Figure 4). Since TSA medium contains $0.25 \%$ glucose, a medium free of sugar such as NA was used to define the role of different carbohydrates in $a c r R^{-}$motility. Thus, when $0.25 \%$ glucose was added to

TABLE 3 | Effect of different compounds over Y. ruckeri acrR derivate strains.

\begin{tabular}{lccc}
\hline Compound & $\boldsymbol{P}$ & $\mathbf{a c r}^{-}$ & $\mathbf{a c r}^{+}$ \\
\hline Acriflavine & 10,24 & 20,48 & 10,24 \\
Ciprofloxacin & 0,08 & 0,32 & 0,04 \\
Chloramphenicol & 5,12 & 10,24 & 2,56 \\
Tetracycline & 0,32 & 0,64 & 0,16 \\
Triton X-100 & 12,8 & 12,8 & ND \\
SDS & 12,8 & 12,8 & ND
\end{tabular}




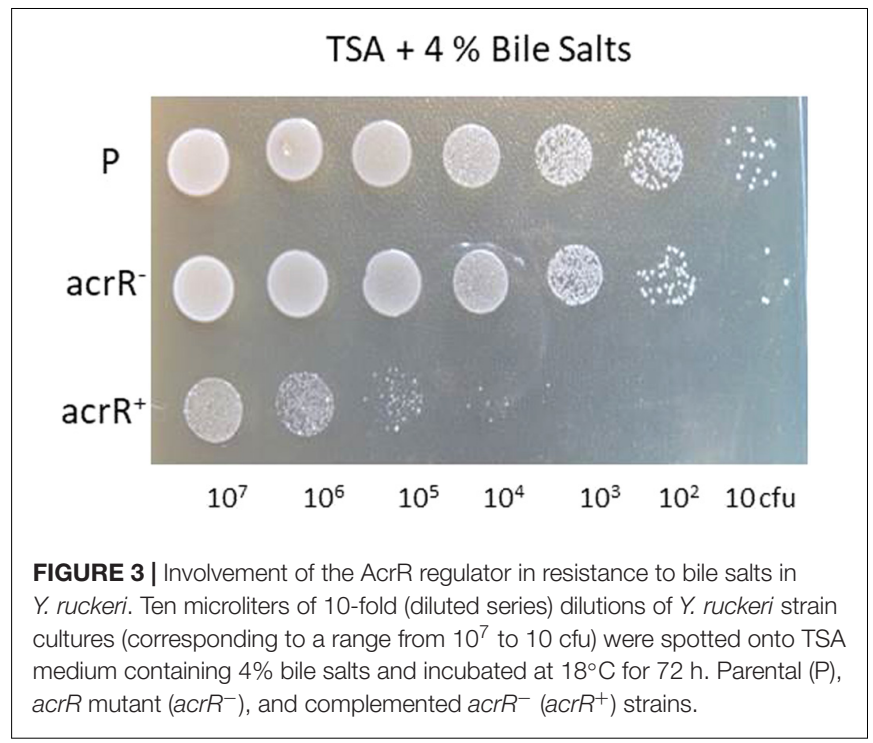

this medium, no motility was observed in any strain, just as occurred in TSA medium (data not shown). However, when the percentage of glucose in NA medium was increased to $0.5 \%$, all the strains showed motility (Figure 4). Other sugars such as galactose, lactose and arabinose did not induced motility in any strain when added to NA medium at $0.5 \%$ or $0.75 \%$ (data not shown). Nevertheless, the presence in the media of glucose at $0.25 \%$ and lactose at $0.5 \%$ only resulted in the motility of the acrR $R^{-}$strain, as occurred when the TSA supplemented with $0.5 \%$ lactose was used (Figure 4). All of these results can be explained by the $\beta$-galactosidase activity displayed by the $a c r R$ mutant that hydrolyses the lactose of the culture medium to glucose and galactose. Neither the parental strain nor the $a c r R^{+}$strain can use lactose, the first because of the lack of lacZY genes in the genome and the second as a consequence of the transcriptional repression of the $a c r R$ promoter, exercised by the overexpression of AcrR encoding in the plasmid used for complementation.

No clear differences in mortality were detected when parental and $\operatorname{acr} R$ mutant strains were administered $\left(10^{6} \mathrm{cfu} / \mathrm{fish}\right)$ by intraperitoneal injection in three groups of five fish (data not shown). For this reason $\mathrm{LD}_{50}$ experiments were carried out. The results obtained confirmed that there were no significant differences between the parental $\left(\mathrm{LD}_{50} 6.3 \times 10^{2} \mathrm{cfu}\right)$ and mutant strains $\left(\mathrm{LD}_{50} 3.8 \times 10^{2} \mathrm{cfu}\right)$. Similarly, when the infection process was carried out by immersion, $90 \%$ of fish died 8 days post infection regardless of the strain inoculated. These results clearly indicate that the inactivation of the acrR gene in Y. ruckeri has no effect on virulence.

\section{Phenotypic Characterization and Virulence Determination of the osm Y Mutant and Complemented Strains osm $Y^{+}$and osm $Y^{++}$}

One of the selected clones presented the transposon inserted into an ORF encoding a 204 amino acid protein homolog to the OsmY protein of E. coli. The Y. ruckeri OsmY protein, according to Blast(p) program, has two BON conserved domains related to osmotic shock cell protection (pfam04972) (Yeats and Bateman, 2003; Zheng et al., 2015). osm $Y$ is flanked at the $5^{\prime}$ end by the factor 3 encoding gene, involved in the release of the peptide chain, and at the opposite end by a gene encoding a 53 amino acid peptide containing the YtjA domain typical of many bacterial membrane proteins (NCBI accession number, COG5487). This genetic structure also appears in other Yersinia species as well as in E. coli K12, Salmonella Typhimurium and Shigella flexneri.

Growth curves in TSB medium of the osm $Y$ mutant and complemented os $m Y^{+}$and $o s m Y^{++}(o s m Y+y t j A)$ strains were

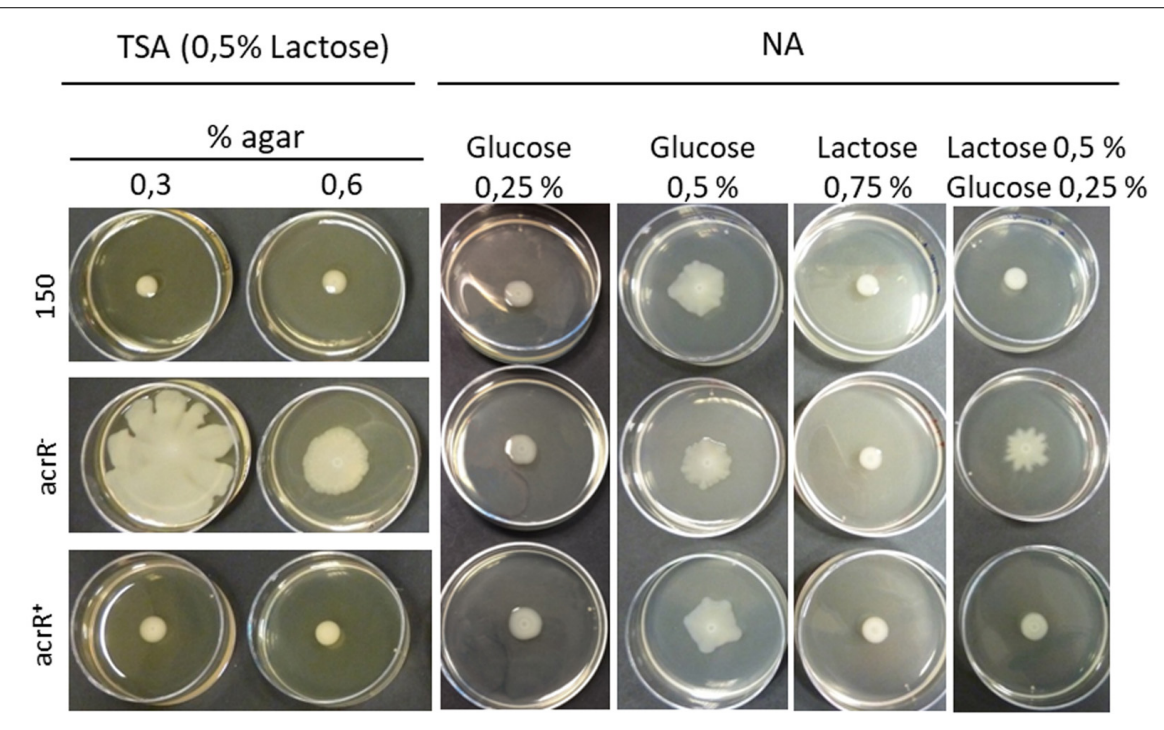

FIGURE 4 | Effect of sugars on the motility of Y. ruckeri. Parental, acrR ${ }^{-}$and acrR ${ }^{+}$strains were spotted onto TSA media containing lactose $0.5 \%$ and $0.3 \%$ or $0.6 \%$ of agar; and in NA with $0.6 \%$ agar and different sugar percentages. Note that all the strains display motility when $0.5 \%$ glucose is present in the medium. 
similar to that of the parental strain (data not shown). Interestingly, when $\mathrm{NaCl}(1.5 \%)$ was added to TSB medium, upregulation of the osm $Y$ gene was observed via bioluminescence emission, showing the relation between this gene and osmotic stress (Supplementary Figure S4).

As was inferred in previous experiments described above, the osm $Y$ mutant was found to be attenuated in virulence. Thus, injection experiments carried out with $10^{6} \mathrm{cfu}$ per fish of parental and $o s m Y$ mutant resulted in $93.3 \%$ mortality and $16.6 \%$ ( $p$-value $0.0165)$, respectively, at 7 days post infection. When $o s m Y^{+}$and os $m \mathrm{Y}^{++}$strains were injected, partial virulence recovery reaching $40 \%$ ( $p$-value 0.0183 ) fish mortality was observed, but only for the latter.

\section{In Vivo and ex Vivo Analysis of acrR and osmY Promoters}

Transcriptional fusion between the $a c r R$ promoter and the lux operon was used for in vivo analysis of the infection process. Fish were infected both by injection or immersion and the light emitted by bacteria through fish tissues was monitored every $24 \mathrm{~h}$ by using the Ivis-Lumina system. Both models of infection began to produce luminescence $48 \mathrm{~h}$ post infection. At that time, high light intensity was located mainly in the liver, in the gut and in the adipose tissue (Figure 5A). A similar result was found when the acrR mutant was confluent grown on TSA plates containing different trout tissues. As can be observed in Figure 5B, maximum luminescence emitted by the acrR mutant corresponded to liver, just as was seen in vivo, although light was also detected in the gut. Interestingly, no luminescence was detected in the adipose tissue. Yersinia ruckeri $a c r R^{+}$did not showed bioluminescence in presence of any fish tissue (Figure 5C).

As expected, according to the virulence attenuation, at $\mathrm{LD}_{50}$ doses no light emission was detected at any time post infection when fish were intraperitoneally injected with the osm $Y$ mutant and $o s m Y^{+}$strains and further examined under Ivis-Lumina equipment (data not shown). However, when the os $m Y^{++}$ complemented strain was used, osm $Y$ expression was highly detected in the gut (Figure 6A), although in many cases high levels of expression in the muscle tissue were found at the end of the infection process, in dead fish (Figure 6B). A similar result was found when rainbow trout tissues were deposited onto TSA media, previously inoculated with $Y$. ruckeri os $m Y^{++}$strain for confluent growth. Thus, the highest luminescence intensity after $24 \mathrm{~h}$ of incubation was observed in bacteria surrounding the muscle (Figure 6C).

\section{DISCUSSION}

In this study, a novel mini Tn5 transposon plasmid, pUT-mini Tn5 lux-lac Km2, was constructed on the backbone of pUT Tn5
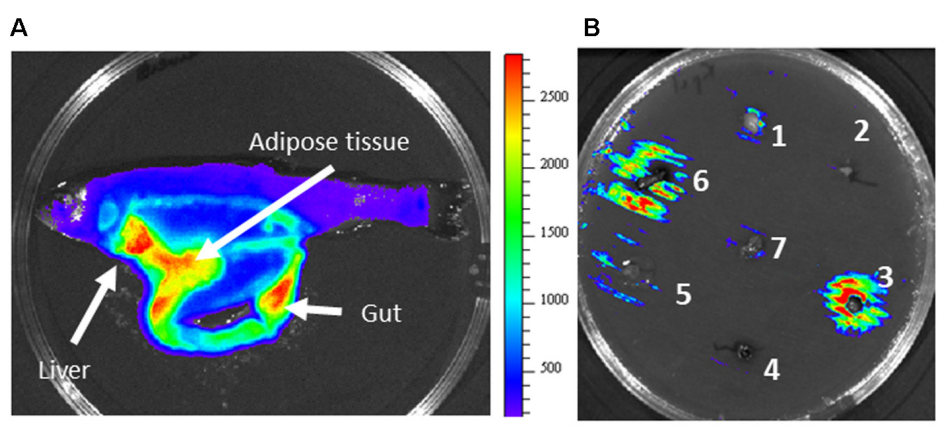

C

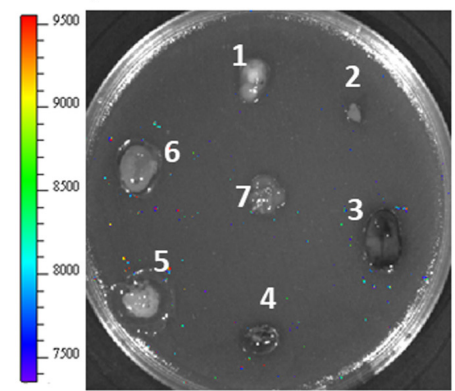

FIGURE 5 | In vivo and in vitro bioluminescence emission by Y. ruckeri acrR $R^{-}$and acr $R^{+}$strains. (A) Fish imaged at 4 days post infection carried out by intraperitoneal injection with the acr $R^{-}$strain. Bioluminescence imaging of acr $R^{-} \mathbf{( B )}$ and acr $R^{+} \mathbf{( C )}$ strains in presence of different fish tissues deposited on TSA plates previously inoculated with the corresponding strain. Brain (1), heart (2), liver (3), spleen (4), adipose tissue (5), gut (6), gills (7). Color bar shows RLU level.

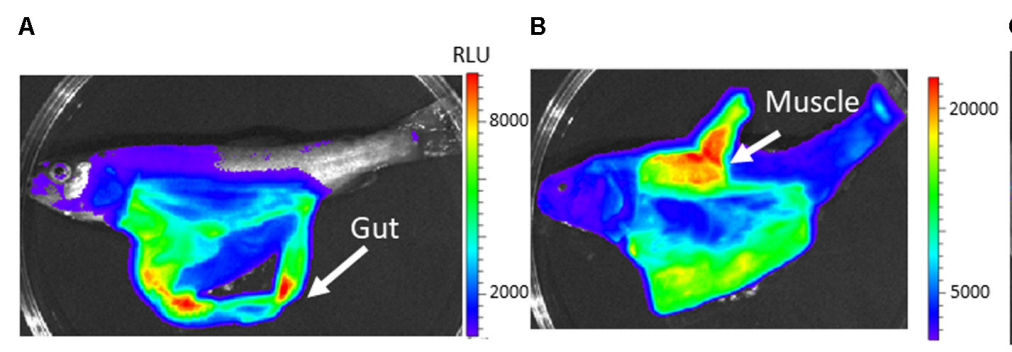

C

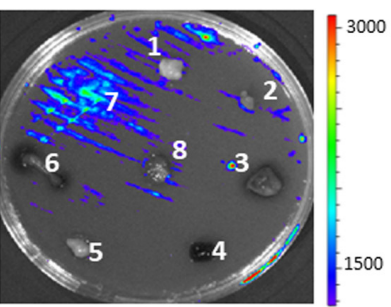

FIGURE 6 | In vivo and in vitro bioluminescence emission by Y. ruckeri osm $Y^{++}$strain. Fish intraperitoneally infected with the osm $Y^{++}$strain were visualized at 3 days (A) and 4 days (B) post infection. In vitro expression of osmY in response to different fish tissues deposited on TSA plates (C). Brain (1), heart (2), liver (3), spleen (4), adipose tissue (5), gut (6), muscle (7), gills (8). Color bar shows RLU level. 
Km2 plasmid (de Lorenzo et al., 1990). The main advantage of mutagenesis with this transposon is that its insertion in the bacterial genome not only results in a knockout mutation but also may lead to the production of transcriptional fusions between the promoterless luxCDABE and lacZY operons and the promoter of the interrupted gene. This study demonstrated that the Tn5 lux-lac Km2 transposon was integrated randomly into the genome of Y. ruckeri and was stable in the absence of selective pressure. Additionally, it was confirmed that expression of lux-lac reporter genes has no effect on the growth rate of Y. ruckeri.

A library of Y. ruckeri Tn5 lux-lac Km2 mutants was screened, via detection of $\beta$-galactosidase activity on EMB medium, for differential expression depending on temperature. Thus, a total of 168 clones showed higher expression at $18^{\circ} \mathrm{C}$, the temperature at which outbreaks occurred, than at the optimal growth temperature $\left(28^{\circ} \mathrm{C}\right)$. In 33 of those clones the gene interrupted was identified (Table 2). Interestingly, one of the selected genes was the yrp1, encoding for the metalloprotease Yrp1 (CAC39217.1) (Fernández et al., 2002, 2003). This gene has already been reported to be regulated by temperature, its expression being more active at $18^{\circ} \mathrm{C}$ than at $28^{\circ} \mathrm{C}$ (Fernández et al., 2002). Additionally, up to three different genes disrupted by the transposon encode for proteins involved in the synthesis of legionaminic acid (OEU25698.1, OEU25693.1, ABY48117.1), which strongly supports the involvement of temperature in the regulation of this process (Welch and LaPatra, 2016; Cascales et al., 2017). All of this strongly suggests that the strategy aimed at selecting promoters whose activity is regulated by temperature (highly expressed at $18^{\circ} \mathrm{C}$ in relation to $28^{\circ} \mathrm{C}$ ) was the appropriate one. The selected mutants were grouped according to specific functions:

One group of mutants presented transposon insertions in genes related to response to environmental changes. Among them, the $y f i N$ gene encoding the diguanylate cyclase (OEU26487.1) involved in the synthesis of cyclic di-GMP, a bacterial second messenger related to the control of many bacterial cellular functions such as changes from the transition between sessile and motile bacterial states (Römbling et al., 2013) and virulence (Raterman et al., 2013; Xu et al., 2016). Two other mutants presented transposon insertion in a putative operon of two genes encoding for a glycosyltransferase (OEU24749.1) and a SAM-dependent methyltransferase (OEU24750.1). Both kinds of enzymes have been previously linked to virulence in bacteria such as Haemophilus parasuis (Zhou et al., 2016), Mycobacterium tuberculosis (Berney et al., 2015), and Klebsiella pneumoniae (Ye et al., 2016). Three transcriptional regulators were also found. One of them encodes for a serine/threonine kinase (OEU26573.1) homologous to the anti-sigma factor RsbW from $Y$. frederiksenii which is involved in stress response through modulation of the sigma B factor (Hughes and Mathee, 1998). Another was the regulator YsrR (OEU25024.1), a member of the two component regulatory system YsrRS that in Y. enterocolitica is involved in the regulation of the type III secretion system Ysa-YsP (Walker and Miller, 2004). The third was the AcrR regulator (OEU24368.1), which represses the AcrAB-TolC pump expulsion system (Deng et al., 2013) involved in resistance to toxic compounds. This gene as well as $\operatorname{osm} Y$ (OEU26500.1), a gene induced under osmotic stress, were further analyzed in this work.

Molecular exchanges between bacteria and their environment is mediated by multiple and complex systems. Three genes were selected in relation to this process: $m g t E$ (OEU26742.1) involved in the transport of magnesium, cobalt and nickel and the genes encoding for a MSF family transporter (OEU26751.1) and the PhoE phosphoporin (OEU26976.1). All of them have been previously linked to virulence (Osorio et al., 2004; Andersson and Hughes, 2010; Chen et al., 2013; Coffey et al., 2014).

Another group of interrupted genes has a relationship with transport and the metabolism of sugars. Such is the case of $m g l A$, a component of an ABC transport system (OEU26755.1) involved in galactose uptake (Harayama et al., 1983); a gene coding a glycogen phosphorylase (OEU26568.1) and another one, malQ (OEU26314.1) which forms part of malPQ operon involved in the uptake and degradation of maltodextrin which is the preferential carbon source in E. coli (Boos and Shuman, 1998). In $V$. cholera, it has been described that malQ plays a role in the virulence of the bacterium (Lang et al., 1994).

A major group of selected genes had a relationship with the bacterial membrane and wall. Thus, the interrupted genes of three different clones form part of a cluster encoding for proteins involved in the synthesis of legionaminic acid, a component of the LPS structure. The encoded proteins correspond with a UDP-N-acetylglucosamine 4,6-dehydratase (OEU25693.1), a D-glycerol-D-mano-heptosa-1-phosphate guanosyltransferase (OEU25698.1) and an O-antigen polymerase (ABY48117.1). This cluster is only present in Y. ruckeri serotype O1 (Welch and LaPatra, 2016; Cascales et al., 2017), and vaccination with a strain carrying a deletion of the second gene of the cluster encoding for the nab2 gene, a nonulosonic acid biosynthesis gene ( $n a b$ gene), resulted in absence of protection against yersiniosis infection, showing the importance of this cluster for ERM bacterin vaccine efficiency (Welch and LaPatra, 2016). According to this and to data reported from other bacteria such as Legionella pneumophila (Lüneberg et al., 1998) and Campylobacter jejuni (Zebian et al., 2016), it is possible that legionaminic acid is involved in the virulence of $Y$. ruckeri. Additional selected genes related to the cellular wall were an $\mathrm{O}$-acyltransferase and a polysaccharide deacetylase which are probably involved in peptidoglycan biosynthesis. Two other genes with higher expression at $18^{\circ} \mathrm{C}$ than at $28^{\circ} \mathrm{C}$ are those encoding an $\mathrm{O}$-acyltransferase (OEU26581.1) and a putative deacetylase (OEU25943.1) probably involved in peptidoglycan synthesis. In Streptococcus iniae the polysaccharide deacetylase Pdi is involved in virulence in the hybrid striped bass model and is necessary for survival in whole fish blood.

Another identified gene was related to antitoxin StbD (OUE25145.1) from the StbD/E toxin-antitoxin system (TA). TA systems are related to multiple functions in bacteria and, recently, some authors have suggested that they could in some cases be directly or indirectly related to infection processes in bacteria (Lobato-Márquez et al., 2016).

A mutant in the damX gene coding for a protein involved in cell division (EEP98349.1) was also isolated. In S. typhi (Leclerc 
et al., 1998) and E. coli (Khandige et al., 2016) this gene was necessary for full virulence.

Other two selected mutants had interrupted the gene encoding the ArnC protein (OEU24187.1), which confers resistance to polymyxin, an antibiotic used in the therapy of multidrug-resistant Gram-negative bacterial infections (Evans et al., 1999), and a gene encoding a protein similar to the protein TnsC (OEU24391.1), which is part of the transposition machinery of the $T n 7$ transposon. This kind of transposon is widespread in bacteria and facilitates the accumulation of mobile DNA within the att $\operatorname{Tn} 7$ site in the chromosome leading to the formation of genomic islands (Parks and Peters, 2007).

PsiF (EEQ00620.1) is an inducible protein under phosphate starvation (Metcalf et al., 1990). Its expression is under the control of the PhoB-PhoR two-component system which is involved in virulence, motility and biofilm formation, among others (Lamarche et al., 2008). The selection at outbreak temperature of the gene coding PsiF in Y. ruckeri could be related to a response of the bacterium to phosphate limitation during the infection process.

An interesting selected gene is that encoding an ADPribosyltransferase exoenzyme (KGA50131.1). A large number of these enzymes are toxins involved in covalent modification of host proteins leading to a pathological manifestation. That is the case for different toxin produced by the genus Clostridium (Stiles et al., 2014), the SpvB virulence factor of Salmonella enterica (Lesnick et al., 2001) and A toxin of Pseudomonas aeruginosa (Wick et al., 1990), among others.

Some of the identified genes encode for hypothetical proteins. It is the case of the gene encoding for the hypothetical protein OEU2487.1 harboring a PDDEXK_7 domain characteristic of nucleases involved in DNA restriction methylation-dependent. The encoding gene forms part of an operon together with a gene coding for and AAA type ATPase involved in DNA repair. In the same way, the gene coding for the hypothetic protein KGA49879.1 seems to be part of an operon related to sugar metabolism. Additionally, the gene encoding for the hypothetical protein OEU24382.1 probably forms part of an operon with the gene encoding for a GTP pyrophosphokinase, homolog to RelA/SpoT, which is associated with virulence in different pathogenic bacteria (Klinkenberg et al., 2010; Nguyen et al., 2011; Zhu et al., 2016).

Finally, mention should be made of the gene encoding the esterase YqiA (AJI94468.1), which forms part of an operon including three other genes encoding for an ADP-ribose pyrophosphatase, a membrane protein and an cAMP phosphodiesterase involved in different cellular process, including the expression of virulence factors in $V$. cholera (Skorupski and Taylor, 1997) and V. vulnificus (Jeong et al., 2001; Choi et al., 2002).

\section{Role of acrR and osm Y Genes and Their Expression During Infection}

As expected, the absence of the $a c r R$ gene in $Y$. ruckeri resulted in an increase in the resistance to a wide variety of toxic compounds that are extruded by the AcrAB-TolC system, including chloramphenicol or tetracycline as well as n-hexane, among others. Epidemiological data indicate that in Y. ruckeri, tetracycline resistance genes also confer resistance to oxytetracycline, a compound used in the treatment of red mouth disease (Balta et al., 2010). According to the study of Balta et al. (2010) $47.6 \%$ of isolated oxytetracycline-resistant Y. ruckeri strains harbored the tet $A$ and tet $B$ genes. In the other strains, resistance to oxytetracycline could be related to an increase in the AcrAB-TolC system activity, resulting from a simple $a c r R$ mutation which would be further selected during antibiotic treatments.

Bile salts induce the expression of the E. coli AcrAB-TolC system (Rosenberg et al., 2003). Although the expression of this pump is subject to complex regulation, it is activated by compounds which come into contact with the bacteria. In this way, Y. ruckeri, as an intestinal pathogen, is highly resistant to bile salts given that $4 \%$ of these compounds allowed the growth of both parental and $a c r R^{-}$strains. Interestingly, the complemented acrR strain was more sensitive to bile salts as well as to tetracycline, ciprofloxacin and chloramphenicol than the parental and mutant strains. This indicates that in the complemented strain the AcrAB pump is highly repressed by AcrR, which in turn suggests that the AcrAB pump is involved in the expulsion of bile salts from Y. ruckeri.

It has been previously reported that in E. coli, AcrR is involved in swimming and swarming motilities, both mediated by flagella, and necessary to evade toxic compounds (Inoue et al., 2007; Kim et al., 2016). In this sense, it seems that the role of AcrR goes beyond the repression of the AcrAB-TolC system. However, our data indicate that the increase in motility detected for the $Y$. ruckeri acrR mutant strain was not a consequence of this mutation, but of the presence in the culture media of a minimum proportion of $0.5 \%$ of glucose, part of which originated from lactose degradation. Thus, in the presence of $0.5 \%$ glucose, the parental, acrR mutant and complemented strains displayed motility. In Y. ruckeri, this relationship between glucose and motility seems to be specific since other sugars did not produce any effect on motility. In Salmonella Typhimurium and $E$. coli, the presence of glucose in the medium was necessary for swarming, probably because it provides the energy needed for the process (Harshey, 1994; Inoue et al., 2007; Kim et al., 2016). However, gliding motility in Clostridium perfringens is repressed by sugars such as glucose, lactose and galactose (Mendez et al., 2008) and swarming motility in Pseudomonas aeruginosa is limited by the presence of glucose (Shrout et al., 2006), indicating that effect of glucose in the motility of bacteria is species-specific.

In spite of being a gene regulated by temperature, acrR was not involved in the infection process when $Y$. ruckeri was infected either by intraperitoneal via or by bath immersion. Different studies indicate that the interruption of the AcrAB-TolC system resulted in virulence attenuation of $S$. Typhimurium (Lacroix et al., 1996), Klebsiella pneumoniae (Padilla et al., 2010), Enterobacter cloacae (Perez et al., 2012), Francisella tularensis (Bina et al., 2008) and the fish pathogen E. tarda (Hou et al., 2009). However, there are some exceptions to this, such as the case of $Y$. pestis in which the AcrAB does not play an essential role in the pathogenic process (Lister et al., 2012), something that also seems to occur in $Y$. ruckeri. 
Although its role is still unknown, induction of the osm $Y$ gene of $Y$. ruckeri in presence of $\mathrm{NaCl}$ confirms the relation between this gene and osmotic stress, as occurred in E. coli (Yim and Villarejo, 1992; Yim et al., 1994). The fact that mutation of the $\operatorname{osm} Y$ gene resulted in a decrease in the virulence of the bacterium showed its importance in the development of the infection process. Perhaps the role it plays has to do with a response to the high molarities present in the fish gut. In any case, not only is the osm $Y$ gene involved in the stress response, but also the adjacent one, $y t j A$, given that complementation of the osm $Y$ mutant strain with both osm $Y$ and $y t j A$ genes was necessary to achieve partial virulence recovery. There are not much data on the role and involvement of $\operatorname{osm} Y$ in bacterial virulence but some indirect relationship was found in $S$. Typhimurium (Bader et al., 2003). Zheng et al. (2015) suggested that osmY could play a role during the initial period of infection where the bacterium has to survive osmotic gut stress. This gene was also linked to the infection processes caused by Cronobacter sakazakii (Ye et al., 2015) and E. coli (Dong and Schellhorn, 2009).

Using the lux operon as reporter gene, it was possible to follow the acrR and osm $Y$ gene expression in different fish tissues. Interestingly, in vivo experiments showed that light emission of $\operatorname{acr} R$ was higher in gut, liver and adipose tissue, where toxic compounds are usually accumulated, whereas osm $Y$ showed higher levels of light in the gut, probably mediated by the osmotic stress generated in the bacterium in this organ. Nevertheless, the high level of luminescence detected after septicaemia in muscle tissue in many of the fish analyzed indicates that osm $Y$ expression could depend on the infection state.

These results are in agreement with those obtained on plates using rainbow trout tissues. Therefore, maximum luminescence resulting from $a c r R$ promoter activity was also detected in gut and liver, although, adipose tissue did not give a high level of light probably because this tissue, once out of the fish, was rapidly altered by fatty acid oxidation. In the same way,

\section{REFERENCES}

Aguado-Urda, M., Gibello, A., Blanco, M., del, M., Fernández-Garayzábal, J. F., López-Alonso, V., et al. (2013). Global transcriptome analysis of Lactococcus garvieae strains in response to temperature. PLoS One 8:e79692. doi: 10.1371/ journal.pone.0079692

Andersson, D. I., and Hughes, D. (2010). Antibiotic resistance and its cost: is it possible to reverse resistance? Natl. Rev. Microbiol. 8, 260-271. doi: 10.1038/ nrmicro2319

Arias, C. R., Olivares-Fuster, O., Hayden, K., Shoemaker, C. A., Grizzle, J. M., and Klesius, P. H. (2007). U.S. department of agriculture, agricultural research service, aquatic animal health research laboratory, post office box 952, Auburn, Alabama, 36830, USA First report of Yersinia ruckeri biotype 2 in the USA. J. Aquat. Anim. Health 19, 35-40. doi: 10.1577/H06-011.1

Bader, M. W., Navarre, W. W., Shiau, W., Nikaido, H., Frye, J. G., McClelland, M., et al. (2003). Regulation of Salmonella typhimurium virulence gene expression by cationic antimicrobial peptides: Salmonella response to antimicrobial peptides. Mol. Microbiol. 50, 219-230. doi: 10.1046/j.1365-2958.2003. 03675.x

Balta, F., Sandalli, C., Kayis, S., and Ozgumus, O. B. (2010). Molecular analysis of antimicrobial resistance in Yersinia ruckeri strains isolated from rainbow trout (Oncorhynchus mykiss) grown in commercial fish farms in Turkey. Bull. Eur. Assoc. Fish Pathol. 30, 211-219. the osm $Y$ gene showed the highest light emission in muscle tissue. Bioluminescence-based bacterial reporter genes are useful to identify and study in vitro and in vivo gene regulation (Méndez and Guijarro, 2013; van Zyl et al., 2015). This result, together with that obtained using randomly selected clones cultivated in the presence of rainbow trout tissues, indicates that plate assays seem to be useful to determine $Y$. ruckeri differential gene expression in trout tissues. This approach allows the number of fish used in the experiments to be reduced, thus making the analyses easier and faster.

\section{AUTHOR CONTRIBUTIONS}

DC performed most of the experiments and analysis of results. AG-T participated in some of the experiments and analysis of results. JM participated in experimental design, experimental work, and critically revised the results. JG participated in experimental design, data analysis, and wrote the paper. DC, JM, AG-T, and JG drafted the first version of the manuscript. All authors reviewed the final version of the manuscript.

\section{FUNDING}

This research was supported by the AGL2012-35808 and AGL2015-66018-R grants from the Ministerio de Economía y Competitividad of Spain. Desiree Cascales and Ana Isabel Garcia were the recipients of FPU and FPI fellowships, respectively.

\section{SUPPLEMENTARY MATERIAL}

The Supplementary Material for this article can be found online at: https://www.frontiersin.org/articles/10.3389/fmicb. 2018.01098/full\#supplementary-material

Berney, M., Berney-Meyer, L., Wong, K. W., Chen, B., Chen, M., Kim, J., et al. (2015). Essential roles of methionine and S-adenosylmethionine in the autarkic lifestyle of Mycobacterium tuberculosis. Proc. Natl. Acad. Sci. U.S.A. 112, 10008-10013. doi: 10.1073/pnas.1513033112

Bina, X. R., Lavine, C. L., Miller, M. A., and Bina, J. E. (2008). The AcrAB RND efflux system from the live vaccine strain of Francisella tularensis is a multiple drug efflux system that is required for virulence in mice. FEMS Microbiol. Lett. 279, 226-233. doi: 10.1111/j.1574-6968.2007.01033.x

Bjarnason, J., Southward, C. M., and Surette, M. G. (2003). Genomic profiling of iron-responsive genes in Salmonella enterica serovar Typhimurium by high-throughput screening of a random promoter library. J. Bacteriol. 185, 4973-4982. doi: 10.1128/JB.185.16.4973-4982.2003

Boos, W., and Shuman, H. (1998). Maltose/maltodextrin system of Escherichia coli: transport, metabolism, and regulation. Microbiol. Mol. Biol. Rev. 62, 204-229.

Calvez, S., Gantelet, H., Blanc, G., Douet, D. G., and Daniel, P. (2014). Yersinia ruckeri biotypes 1 and 2 in France: presence and antibiotic susceptibility. Dis. Aquat. Organ. 109, 117-126. doi: 10.3354/dao02725

Cascales, D., Guijarro, J. A., García-Torrico, A. I., and Méndez, J. (2017). Comparative genome analysis reveals important genetic differences among serotype $\mathrm{O} 1$ and serotype $\mathrm{O} 2$ strains of $Y$. ruckeri and provides insights into host adaptation and virulence. Microbiologyopen 6:e460. doi: 10.1002/mbo3.460 Chakraborty, S., Li, M., Chatterjee, C., Sivaraman, J., Leung, K. Y., and Mok, Y.-K. (2010). Temperature and Mg+ sensing by a Novel PhoP-PhoQ two-component 
system for regulation of virulence in Edwardsiella tarda. J. Biol. Chem. 285, 38876-38888. doi: 10.1074/jbcM110.179150

Chen, S., Wang, H., Katzianer, D. S., Zhong, Z., and Zhu, J. (2013). LysR family activator-regulated major facilitator superfamily transporters are involved in Vibrio cholerae antimicrobial compound resistance and intestinal colonization. Int. J. Antimicrob. Agents 41, 188-192. doi: 10.1016/j.ijantimicag.2012.10.008

Choi, H. K., Park, N. Y., Kim, D.-I., Chung, H. J., Ryu, S., and Choi, S. H. (2002). Promoter analysis and regulatory characteristics of $v v h \mathrm{BA}$ encoding cytolytic hemolysin of Vibrio vulnificus. J. Biol. Chem. 277, 47292-47299. doi: 10.1074/ jbc.M206893200

Cipriano, R. C., and Holt, R. A. (2005). Flavobacterium psychrophilum, Cause of Bacterial Cold Water Disease and Rainbow Trout Fry Syndrome. Fish Disease Leaflet No. 86. Kearneysville, WV: United States Department of the Interior.

Coffey, B. M., Akhand, S. S., and Anderson, G. G. (2014). MgtE is a dual-function protein in Pseudomonas aeruginosa. Microbiology 160, 1200-1213. doi: 10.1099/ mic.0.075275-0

Davies, R. L., and Frerichs, G. N. (1989). Morphological and biochemical differences among isolates of Yersinia ruckeri obtained from wide geographical areas. J. Fish Dis. 12, 357-365. doi: 10.1111/j.1365-2761.1989.tb00324.x

de Lorenzo, V., Herrero, M., Jakubzik, U., and Timmis, K. N. (1990). Mini Tn5 transposon derivatives for insertion mutagenesis, promoter probing, and chromosomal insertion of cloned DNA in gram-negative eubacteria. J. Bacteriol. 172, 6568-6572. doi: 10.1128/jb.172.11.6568-6572.1990

Deng, W., Li, C., and Xie, J. (2013). The underling mechanism of bacterial TetR/AcrR family transcriptional repressors. Cell. Signal. 25, 1608-1613. doi: 10.1016/j.cellsig.2013.04.003

Denton, J. E., Yousef, M. K., Yousef, I. M., and Kuksis (1974). Bile acid composition of rainbow trout, Salmo gairdneri. Lipids 9, 945-951. doi: 10.1007/BF02533816

Dong, T., and Schellhorn, H. E. (2009). Global effect of RpoS on gene expression in pathogenic Escherichia coli O157:H7 strain EDL933. BMC Genomics 10:349. doi: 10.1186/1471-2164-10-349

Enger, O., Husevag, B., and Goksoyr, J. (1991). Seasonal variation in presence of Vibrio salmonicida and total bacterial counts in Norwegian fish- farm water. Can. J. Microbiol. 37, 618-623. doi: 10.1139/m91-105

Evans, M. E., Feola, D. J., and Rapp, R. P. (1999). Polymyxin B sulfate and colistin: old antibiotics for emerging multiresistant gram-negative bacteria. Ann. Pharmacother. 33, 960-967. doi: 10.1345/aph.18426

Fernández, L., Lopez, J. R., Secades, P., Menendez, A., Marquez, I., and Guijarro, J. A. (2003). In vitro and in vivo studies of the Yrp1 protease from Yersinia ruckeri and its role in protective immunity against enteric red mouth disease of salmonids. Appl. Environ. Microbiol. 69, 7328-7335. doi: 10.1128/AEM.69.12. 7328-7335.2003

Fernández, L., Marquez, I., and Guijarro, J. A. (2004). Identification of specific in vivo-induced (ivi) genes in Yersinia ruckeri and analysis of ruckerbactin, a catecholate siderophore iron acquisition system. Appl. Environ. Microbiol. 70, 5199-5207. doi: 10.1128/AEM.70.9.5199-5207.2004

Fernández, L., Méndez, J., and Guijarro, J. A. (2007a). Molecular virulence mechanisms of the fish pathogen Yersinia ruckeri. Vet. Microbiol. 125, 1-10. doi: 10.1016/j.vetmic.2007.06.013

Fernández, L., Prieto, M., and Guijarro, J. A. (2007b). The iron- and temperatureregulated haemolysin YhlA is a virulence factor of Yersinia ruckeri. Microbiology 153, 483-489. doi: 10.1099/mic.0.29284-0

Fernández, L., Secades, P., Lopez, J. R., Márquez, I., and Guijarro, J. A. (2002). Isolation and analysis of a protease gene with an $\mathrm{ABC}$ transport system in the fish pathogen Yersinia ruckeri: insertional mutagenesis and involvement in virulence. Microbiology 148, 2233-2243. doi: 10.1099/00221287-148-7-2233

Guijarro, J. A., Cascales, D., García-Torrico, A. I., García-Domínguez, M., and Méndez, J. (2015). Temperature-dependent expression of virulence genes in fish-pathogenic bacteria. Front. Microbiol. 6:700. doi: 10.3389/fmicb.2015.00700

Harayama, S., Bollinger, J., Iino, T., and Hazelbauer, G. L. (1983). Characterization of the $m g l$ operon of Escherichia coli by transposon mutagenesis and molecular cloning. J. Bacteriol. 153, 408-415.

Harshey, R. M. (1994). Bees aren't the only ones: swarming in gram-negative bacteria. Mol. Microbiol. 13, 389-394. doi: 10.1111/j.1365-2958.1994.tb00433.x

Herrero, M., de Lorenzo, V., and Timmis, K. N. (1990). Transposon vectors containing non-antibiotic resistance selection markers for cloning and stable chromosomal insertion of foreign genes in Gram-negative bacteria. J. Bacteriol. 172, 6557-6567. doi: 10.1128/jb.172.11.6557-6567.1990
Hesami, S., Metcalf, D. S., Lumsden, J. S., and Macinnes, J. I. (2011). Identification of cold-temperature-regulated genes in Flavobacterium psychrophilum. Appl. Environ. Microbiol. 77, 1593-1600. doi: 10.1128/AEM.01717-10

Hou, J., Hu, Y., Zhang, M., and Sun, L. (2009). Identification and characterization of the AcrR/AcrAB system of a pathogenic Edwardsiella tarda strain. J. Gen. Appl. Microbiol. 55, 191-199. doi: 10.2323/jgam.55.191

Hughes, K. T., and Mathee, K. (1998). The anti-sigma factors. Annu. Rev. Microbiol. 52, 231-286. doi: 10.1146/annurev.micro.52.1.231

Inoue, T., Shingaki, R., Hirose, S., Waki, K., Mori, H., and Fukui, K. (2007). Genome-wide screening of genes required for swarming motility in Escherichia coli K-12. J. Bacteriol. 189, 950-957. doi: 10.1128/JB.01294-06

Jeong, H. S., Jeong, K. C., Choi, H. K., Park, K.-J., Lee, K.-H., Rhee, J. H., et al. (2001). Differential expression of Vibrio vulnificus elastase gene in a growth phase-dependent manner by two different types of promoters. J. Biol. Chem. 276, 13875-13880. doi: 10.1074/jbc.M010567200

Khandige, S., Asferg, C. A., Rasmussen, K. J., Larsen, M. J., Overgaard, M., Andersen, T. E., et al. (2016). DamX controls reversible cell morphology switching in uropathogenic Escherichia coli. mBio 7:e00642-16. doi: 10.1128/ mBio.00642-16

Kim, Y. J., Im, S. Y., Lee, J. O., and Kim, O. B. (2016). Potential swimming motility variation by AcrR in Escherichia coli. J. Microbiol. Biotechnol. 26, 1824-1828. doi: 10.4014/jmb.1607.07058

Klinkenberg, L. G., Lee, J., Bishai, W. R., and Karakousis, P. C. (2010). The stringent response is required for full virulence of Mycobacterium tuberculosis in guinea pigs. J. Infect. Dis. 202, 1397-1404. doi: 10.1086/656524

Kumar, G., Menanteau-Ledouble, S., Saleh, M., and El-Matbouli, M. (2015). Yersinia ruckeri, the causative agent of enteric redmouth disease in fish. Vet. Res. 46, 103-123. doi: 10.1186/s13567-015-0238-4

Lacroix, F. J., Cloeckaert, A., Grépinet, O., Pinault, C., Popoff, M. Y., Waxin, H., et al. (1996). Salmonella typhimurium acrB-like gene: identification and role in resistance to biliary salts and detergents and in murine infection. FEMS Microbiol. Lett. 135, 161-167. doi: 10.1111/j.1574-6968.1996.tb07983.x

Lamarche, M. G., Wanner, B. L., Crepin, S., and Harel, J. (2008). The phosphate regulon and bacterial virulence: a regulatory network connecting phosphate homeostasis and pathogenesis. FEMS Microbiol. Rev. 32, 461-473. doi: 10.1111/ j.1574-6976.2008.00100.x

Lang, H., Jonson, G., Holmgren, J., and Palva, E. T. (1994). The maltose regulon of Vibrio cholerae affects production and secretion of virulence factors. Infect. Immun. 62, 4781-4788.

Leclerc, G. J., Tartera, C., and Metcalf, E. S. (1998). Environmental regulation of Salmonella typhi invasion-defective mutants. Infect. Immun. 66, 682-691.

Lesnick, M. L., Reiner, N. E., Fierer, J., and Guiney, D. G. (2001). The Salmonella $\operatorname{spvB}$ virulence gene encodes an enzyme that ADP-ribosylates actin and destabilizes the cytoskeleton of eukaryotic cells. Mol. Microbiol. 39, 1464-1470. doi: 10.1046/j.1365-2958.2001.02360.x

Lister, I. M., Raftery, C., Mecsas, J., and Levy, S. B. (2012). Yersinia pestis acrABtolC in antibiotic resistance and virulence. Antimicrob. Agents Chemother. 56, 1120-1123. doi: 10.1128/AAC.05338-11

Lobato-Márquez, D., Díaz-Orejas, R., and García-del Portillo, F. (2016). Toxinantitoxins and bacterial virulence. FEMS Microbiol. Rev. 40, 592-609. doi: 10 1093/femsre/fuw022

Lüneberg, E., Zähringer, U., Knirel, Y. A., Steinmann, D., Hartmann, M., Steinmetz, I., et al. (1998). Phase-variable expression of lipopolysaccharide contributes to the virulence of Legionella pneumophila. J. Exp. Med. 188:49. doi: $10.1084 /$ jem.188.1.49

Mahan, M. J., Tobias, J. W., Slauch, J. M., Hanna, P. C., Collier, R. J., and Mekalanos, J. J. (1995). Antibiotic-based selection for bacterial genes that are specifically induced during infection of a host. Proc. Natl. Acad. Sci. U.S.A. 92, 669-673. doi: 10.1073/pnas.92.3.669

Manen, D., Pougeon, M., Damay, P., and Geiselmann, J. (1997). A sensitive reporter gene system using bacterial luciferase based on a series of plasmid cloning vectors compatible with derivatives of pBR322. Gene 186, 197-200. doi: 10.1016/S0378-1119(96)00702-0

Meighen, E. A., and Szittner, R. B. (1992). Multiple repetitive elements and organization of the lux operons of luminescence terrestrial bacteria. J. Bacteriol. 174, 5371-5381. doi: 10.1128/jb.174.16.5371-5381.1992

Méndez, J., Fernandez, L., Menendez, A., Reimundo, P., Perez-Pascual, D., Navais, R., et al. (2009). A chromosomally located traHIJKCLMN operon 
encoding a putative Type IV secretion system is involved in the virulence of Yersinia ruckeri. Appl. Environ. Microbiol. 75, 937-945. doi: 10.1128/AEM. 01377-08

Méndez, J., and Guijarro, J. A. (2013). In vivo monitoring of Yersinia ruckeri in fish tissues: progression and virulence gene expression. Environ. Microbiol. Rep. 5, 179-185. doi: 10.1111/1758-2229.12030

Mendez, M., Huang, I. H., Ohtani, K., Grau, R., Shimizu, T., and Sarker, M. R. (2008). Carbon catabolite repression of type IV pilus-dependent gliding motility in the anaerobic pathogen Clostridium perfringens. J. Bacteriol. 190, 48-60. doi: 10.1128/JB.01407-07

Metcalf, W. W., Steed, P. M., and Wanner, B. L. (1990). Identification of phosphate starvation-inducible genes in Escherichia coli K-12 by DNA sequence analysis of psi::lacZ(Mu d1) transcriptional fusions. J. Bacteriol. 172, 3191-3200. doi: 10.1128/jb.172.6.3191-3200.1990

Nguyen, D., Joshi-Datar, A., Lepine, F., Bauerle, E., Olakanmi, O., Beer, K., et al. (2011). Active starvation responses mediate antibiotic tolerance in biofilms and nutrient-limited bacteria. Science 334, 982-986. doi: 10.1126/science.121 1037

Osorio, C. G., Martinez-Wilson, H., and Camilli, A. (2004). The ompU paralogue vca1008 is required for virulence of Vibrio cholera. J. Bacteriol. 186, 5167-5171. doi: 10.1128/JB.186.15.5167-5171.2004

Padilla, E., Llobet, E., Domenech-Sanchez, A., Martinez-Martinez, L., Bengoechea, J. A., and Alberti, S. (2010). Klebsiella pneumoniae AcrAB efflux pump contributes to antimicrobial resistance and virulence. Antimicrob. Agents Chemother. 54, 177-183. doi: 10.1128/AAC.00715-09

Parks, A. R., and Peters, J. E. (2007). Transposon Tn7 is widespread in diverse bacteria and forms genomic islands. J. Bacteriol. 189, 2170-2173. doi: 10.1128/ JB.01536-06

Perez, A., Poza, M., Fernandez, A., Fernandez Mdel, C., Mallo, S., Merino, M., et al. (2012). Involvement of the AcrAB-TolC efflux pump in the resistance, fitness, and virulence of Enterobacter cloacae. Antimicrob. Agents Chemother. 56, 2084-2090. doi: 10.1128/AAC.05509-11

Raterman, E. L., Shapiro, D. D., Stevens, D. J., Schwartz, K. J., and Welch, R. A. (2013). Genetic analysis of the role of $y f i R$ in the ability of Escherichia coli CFT073 to control cellular cyclic dimeric GMP levels and to persist in the urinary tract. Infect. Immun. 81, 3089-3098. doi: 10.1128/IAI. 01396-12

Reed, L. J., and Muench, H. (1938). A simple method of estimating fifty per cent endpoints. Am. J. Epidemiol. 27, 493-497. doi: 10.1093/oxfordjournals.aje. a118408

Romalde, J. L., Magariños, B., Barja, J. L., and Toranzo, A. E. (1993). Antigenic and molecular characterization of Yersinia ruckeri proposal for a new intraspecies classification. Syst. Appl. Microbiol. 16, 411-419. doi: 10.1016/S0723-2020(11) 80274-2

Römbling, U., Galperin, M. Y., and Gomelsky, M. (2013). Cyclic di-GMP: the first 25 years of a universal bacterial second messenger. Microbiol. Mol. Biol. Rev. 77, 1-52. doi: 10.1128/MMBR.00043-12

Rosenberg, E. Y., Bertenthal, D., Nilles, M. L., Bertrand, K. P., and Nikaido, H. (2003). Bile salts and fatty acids induce the expression of Escherichia coli AcrAB multidrug efflux pump through their interaction with Rob regulatory protein: binding of bile salts to Rob regulates AcrAB expression. Mol. Microbiol. 48, 1609-1619. doi: 10.1046/j.1365-2958.2003.03531.x

Shrout, J. D., Chopp, D. L., Just, C. L., Hentzer, M., Givskov, M., and Parsek, M. R. (2006). The impact of quorum sensing and swarming motility on Pseudomonas aeruginosa biofilm formation is nutritionally conditional. Mol. Microbiol. 62, 1264-1277. doi: 10.1111/j.1365-2958.2006.05421.x

Simon, R., Priefer, U., and Pühler, A. (1983). A broad host range mobilization system for in vivo genetic engineering: transposon mutagenesis in gram negative bacteria. Nat. Biotechnol. 1, 784-791. doi: 10.1038/nbt $1183-784$

Skorupski, K., and Taylor, R. K. (1997). Cyclic AMP and its receptor protein negatively regulate the coordinate expression of cholera toxin and toxincoregulated pilus in Vibrio cholera. Proc. Natl. Acad. Sci. U.S.A. 94, 265-270. doi: 10.1073/pnas.94.1.265

Srinivasa Rao, P. S., Lim, T. M., and Leung, K. Y. (2003). Functional genomic approach to the identification of virulence genes involved in Edwardsiella tarda pathogenesis. Infect. Immun. 71, 1343-1351. doi: 10.1128/IAI.71.3.1343-1351. 2003
Srinivasa Rao, P. S., Yamada, Y., Tan, Y. P., and Leung, K. Y. (2004). Use of proteomics to identify novel virulence determinants that are requires for Edwardsiella tarda pathogenesis. Mol. Microbiol. 53, 573-586. doi: 10.1111/j. 1365-2958.2004.04123.x

Stiles, B. G., Pradhan, K., Fleming, J. M., Samy, R. P., Barth, H., and Popoff, M. R. (2014). Clostridium and Bacillus binary enterotoxins: bad for the bowels, and eukaryotic being. Toxin 6, 2626-2656. doi: 10.3390/toxins609 2626

Tobback, E., Decostere, A., Hermans, K., Haesebrouck, F., and Chiers, K. (2007). Yersinia ruckeri infections in salmonid fish. J. Fish Dis. 30, 257-268. doi: 10.1111/j.1365-2761.2007.00816.x

van Zyl, W. F., Deane, S. M., and Dicks, L. M. (2015). Reporter systems for in vivo tracking of lactic acid bacteria in animal model studies. Gut Microbes 6, 291-299. doi: 10.1080/19490976.2015.1086058

Vendrell, D., Balcázar, J. L., Ruiz-Zarzuela, I., de Blas, I, Gironés, O., and Múzquiz, J. L. (2006). Lactococcus garvieae in fish: a review. Comp. Immunol. Microbiol. Infect. Dis. 29, 177-198. doi: 10.1016/j.cimid2006.06.003

Walker, K. A., and Miller, V. L. (2004). Regulation of the Ysa type III secretion system of Yersinia enterocolitica by YsaE/SycB and YsrS/YsrR. J. Bacteriol. 186, 4056-4066. doi: 10.1128/JB.186.13.4056-4066.2004

Wang, X., Wang, Q., Xiao, J., Liu, Q., Wu, H., Xu, L., et al. (2009). Edwardsiella tarda T6SS component evpP is regulated by esrB and iron, and plays essential roles in the invasion of fish. Fish Shellfish Inmunol. 27, 469-477. doi: 10.1016/j. fsi.2009.06.013

Welch, T. J., and LaPatra, S. (2016). Yersinia ruckeri lipopolysaccharide is necessary and sufficient for eliciting a protective immune response in rainbow trout (Oncorhynchus mykiss, Walbaum). Fish Shellfish Immunol. 49, 420-426. doi: 10.1016/j.fsi.2015.12.037

Wick, M. J., Hamood, A. N., and Iglewski, B. H. (1990). Analysis of the structurefunction relationship of Pseudomonas aeruginosa exotoxin A. Mol. Microbiol. 4, 527-535. doi: 10.1111/j.1365-2958.1990.tb00620.x

Woodcock, D. M., Crowther, P. J., Doherty, J., Jefferson, S., De Cruz, E., Noyer-Weidner, M., et al. (1989). Quantitative evaluation of Escherichia coli host strains for tolerance to cytosine methylation in plasmid and phage recombinants. Nucleic Acids Res. 17, 3469-3478. doi: 10.1093/nar/17.9. 3469

Xu, M., Yang, X., Yang, X.-A., Zhou, L., Liu, T.-Z., Fan, Z., et al. (2016). Structural insights into the regulatory mechanism of the Pseudomonas aeruginosa YfiBNR system. Protein Cell 7, 403-416. doi: 10.1007/s13238-016-0264-7

Ye, M., Tu, J., Jiang, J., Bi, Y., You, W., Zhang, Y., et al. (2016). Clinical and genomic analysis of liver abscess-causing Klebsiella pneumoniae identifies new liver abscess-associated virulence genes. Front. Cell. Infect. Microbiol. 6:165. doi: 10.3389/fcimb.2016.00165

Ye, Y., Gao, J., Jiao, R., Li, H., Wu, Q., Zhang, J., et al. (2015). The membrane proteins involved in virulence of Cronobacter sakazakii virulent G362 and attenuated L3101 isolates. Front. Microbiol. 6:1238. doi: 10.3389/fmicb.2015. 01238

Yeats, C., and Bateman, A. (2003). The BON domain: a putative membranebinding domain. Trends Biochem. Sci. 28, 352-355. doi: 10.1016/S09680004(03)00115-4

Yim, H. H., Brems, R. L., and Villarejo, M. (1994). Molecular characterization of the promoter of osmY, an rpoS-dependent gene. J. Bacteriol. 176, 100-107. doi: 10.1128/jb.176.1.100-107.1994

Yim, H. H., and Villarejo, M. (1992). osm Y, a new hyperosmotically inducible gene, encodes a periplasmic protein in Escherichia coli. J. Bacteriol. 174, 3637-3644. doi: 10.1128/jb.174.11.3637-3644.1992

Yu, H. B., Kaur, R., Lim, S., Wang, X. H., and Leung, K. Y. (2007). Characterization of extracellular proteins produced by Aeromonas hydrophila AH-1. Proteomics 7, 436-449. doi: 10.1002/pmic.200600396

Zebian, N., Merkx-Jacques, A., Pittock, P. P., Houle, S., Dozois, C. M., Lajoie, G. A., et al. (2016). Comprehensive analysis of flagellin glycosylation in Campylobacter jejuni NCTC 11168 reveals incorporation of legionaminic acid and its importance for host colonization. Glycobiology 26, 386-397. doi: 10.1093/glycob/cwv104

Zheng, J., Tung, S. L., and Leung, K. Y. (2005). Regulation of a type III and putative secretion system in Edwardsiella tarda by EsrC is under the control of a two-component system EsrA-EsrB. Infect. Immun. 73, 4127-4137. doi: 10.1128/IAI.73.7.4127-4137.2005 
Zheng, X., Ji, Y., Weng, X., and Huang, X. (2015). RpoS-dependent expression of OsmY in Salmonella enterica serovar Typhi: activation under stationary phase and SPI-2-inducing conditions. Curr. Microbiol. 70, 877-882. doi: 10.1007/ s00284-015-0802-1

Zhou, Q., Feng, S., Zhang, J., Jia, A., Yang, K., Xing, K., et al. (2016). Two glycosyltransferase genes of Haemophilus parasuis SC096 implicated in lipooligosaccharide biosynthesis, serum resistance, adherence, and invasion. Front. Cell. Infect. Microbiol. 6:100. doi: 10.3389/fcimb.2016.00100

Zhu, J., Zhang, T., Su, Z., Li, L., Wang, D., Xiao, R., et al. (2016). (p)ppGpp synthetases regulate the pathogenesis of zoonotic Streptococcus suis. Microbiol. Res. 191, 1-11. doi: 10.1016/j.micres.2016.05.007
Conflict of Interest Statement: The authors declare that the research was conducted in the absence of any commercial or financial relationships that could be construed as a potential conflict of interest.

Copyright (c) 2018 Mendez, Cascales, Garcia-Torrico and Guijarro. This is an openaccess article distributed under the terms of the Creative Commons Attribution License (CC BY). The use, distribution or reproduction in other forums is permitted, provided the original author(s) and the copyright owner are credited and that the original publication in this journal is cited, in accordance with accepted academic practice. No use, distribution or reproduction is permitted which does not comply with these terms. 